\section{Information Society, Work and the Generation of New Forms of Social Exclusion (SOWING) - the Theoretical Approach *}

von Gerd Schienstock, Universität Tampere, Gotthard Bechmann und Günther Frederichs, ITAS

\section{Preface}

The international project "Information Society, Work and the Generation of New Forms of Social Exclusion", in which ITAS is participating from Germany, has been supported in the framework of TSER since January 1998. The "Targeted Socio-Economic Research Programme" of the European Union consists of the three areas "Evaluation of science and technology policy options in Europe", "Research on education and training" and "Research into social exclusion and social integration in Europe". Among the goals of this research programme is to produce research results relevant for decision-making for sustainable economic and social development of European national economies (cf. Work programme 1997 - 1998 of 27 June 1997). The technology policy perspective referred to in the first area is now mainly determined by developments toward a global "information society", as indicated at EU level by the "Bangemann Report" of 1994 and the wide variety of corresponding activities (cf. www.ispo.cec.be).

The SOWING project unites research groups from Belgium, Germany, England, Finland, Ireland, Italy, Austria and Portugal. The project is being led by Professor Gerd Schienstock of the "Work Research Centre" of the University of Tampere in Finland. The project is scheduled to be completed in three years. Its aim is to describe the infomatisation of firms in the manufacturing and service industries in selected regions of these countries from a comparable perspective with respect to prevailing technological practices. Benefits of the project are expected with respect to scientific, technological and political goals. From the scientific point of view it represents an approach to investi- gating the information society which unites previously largely independent approaches, mainly of technological, economic or sociological origin. Of particular technological interest is the collection of experience and data on technological application concepts in an international comparison. The political dimension fulfils major expectations of the EU regarding the TSER programme. Thus, research findings are expected which could, for example, be fundamental for region specific decisions and support measures to enhance the global competitiveness of firms in the Member states, but also meeting the needs of job creation and integration policy.

In the project, a research approach was selected, focusing closely on the information society, at the same time still directed towards the overarching economic and social concerns of TSER. The approach consists of the deliberate abandonment of the otherwise widely held opinion that societal change in the direction of an information society is determined solely by the new information and communication technologies. The correction of this conception is suggested by sociological research on technology during the past two or three decades. All precise analyses prove that technological development by no means follows an immanent logic of technology, but is involved in a complex mutual relationship with societal developments. By this inevitable change of perspective, the project gains a conceptual link between "technology" and "society".

The societal dimension of the discussion on an information society refers primarily to the change in economic structures. Correspondingly, the project concentrates on issues of organisation renovation of manufacturing and service companies and on development of the world of work in relation with the diffusion of the new technologies. This diffusion and the broad variety of application forms of information and communication technologies are classified by the bracket term "informatisation". The conceptual instrument for the empirical observation of corresponding changes inside enterprises and their social environment is "technological practice", which is understood in the sense that it encompasses technological and social elements. The versatility of this term is, for example, demonstrated by the fact that it can be used to link with the classic discussion on "enterprise 
culture". Even the case of celibacy with respect to new technologies can be described as "technological practice". The term in particular does not restrict itself to the formal organisational structure of the firm, also extending to the formal and informal structures of the world of work, thus, for instance, adequately addressing the special issue of new forms of social exclusion in connection with the new technologies.

The SOWING-Project deals with various empirical research instruments: firm survey, regional profile study, and case studies of enterprises. In the first step of the project, each of the national research groups had to prepare a literature report giving an overview of the national discourses on the information society. These National Literature Reports were synthesized into the first Interim Report of the project. Furthermore, the national state of the art reports became the basis for the final version of the theoretical framework of the SOWING Project. The present report is based on the National Reports and is part of the Interim Report. *

The aim of the Interim Report is to further develop the conceptual framework for the project. Therefore, those parts of the National Literature Reports were taken into account which could particularly contribute to this objective. With the selection of parts of the Interim Report given here the authors want to present the conceptual discussion in the project. Therefore the published text is a work in progress.

The second contribution "'Standortdebatte' und 'Neue Armut': Bundesdeutsche Illustrationen zum EU-Projekt SOWING" deals with the special historical aspects influencing the development of the Information Society in Germany in the light of SOWING. Vice versa, this results also in an informative illustration of the topics of SOWING in the light of German experiences. German developments like the former "Modell Deutschland" and the recent "Standortdebatte" give the opportunity to demonstrate the comprehensiveness and actuality of this EU project.

\section{Introduction ${ }^{1}$}

Following the argumentation of Stephen J. Gould, we can assume that societies develop rather slowly and steadily over long periods of time. Yet at rare intervals, he continues, major events occur with great rapidity, causing dramatic socio-economic changes but at the same time helping to establish a new area of relative stability (1980: 226). Independent of whether we accept such a gradualism or not, there is widespread agreement that at the end of the twentieth century we are living through one of the rare intervals in which economy and society are being transformed fundamentally and rapidly. It is stated in the so called Bangemann Report' that the changes currently taking place together with the disappearance of the industrial society may become even more dramatic than those caused by the replacement of the agrarian society through the industrial society, as the change process will take place in a much shorter period of time (High Level Group on the Information Society 1996).

Already during the 1970s and 1980s there was a prolific output of general publications proposing the notion that the world was undergoing a 'new industrial revolution', the 'microelectronics revolution', (Forester 1980) and entering a new phase, typically described as 'post-industrial society' (Bell 1976), the information economy' (Porat 1976), or the 'third wave' (Toffler 1980). The notion is postulated that we are entering a new 'techno-economic paradigm', sometimes described as the 'fifth information and communication Kondratieff' (Freeman 1987), an idea reformulated by Castells as the 'informational mode of production' (Castells 1989).

In the recent years, the term 'information society' has taken centre stage in the international debate due to the publication of the Bangemann Report and following political initiatives in various countries. Other terms such as 'service society' (Gershuny and Miles 1983), 'science society' (Drucker 1969), 'knowledge society' (Böhme and Stehr 1986) and 'learning society' (Lundvall and Johnson 1993) have never attracted the same attention.

The notion 'information society' is less a theoretical than a political term. It is present as a strategic aim, in order to overcome the current social stagnation. Whether the European Commission, federal governments or industrial federations; the central argument is that the 'information society' would create and secure millions of new jobs. If one extracts the bones of these many programmatic statements brought 
into connection with the emergence of the information society', it turns out that they are dominated by four main themes: The information society' would supposedly guarantee economic competitiveness and create new jobs; bring ecological advantages; intensify democracy; revolutionise our ways of living and working with the help of new communications technologies.

\section{Basic Concepts of Information Society ${ }^{2}$}

Within academia, the understanding of an information society' differs significantly. The idea of an emerging 'information society' is developed within the framework of various theoretical contexts and not as a theoretical concept in its own right. The literature is interdisciplinary; various social science disciplines such as political economy, business studies, the sociology of organisation, communication and media sciences, political and educational sciences, as well as sociology in general, but also natural and technical sciences have participated and are still participating in the discourse on information society.

One could systematise the debate on information society according to the dimensions in which social change is primarily exemplified. In this respect, one can differentiate between the following concepts:

- The Information Society as an Information Economy

- The Information Society as Post-Industrial Society

- The Information Society as the End of the Industrial Labour Society

- The Information Society as a Knowledge Society

- The Information Society as an Informatised Industrial Society

- The Information Society as a Learning Society

Although these concepts partially overlap, and cannot always be clearly distinguished from one another, they do emphasise the transition to an information society in a specific manner. It is possible to distinguish various aspects of the transformation process.

\subsection{The Information Society as an Information Economy}

The anthropologist and biologist Todao Umesao was one of the first academics to write about the information society. He assigned a key role in the modernisation process to the knowledge industry. In his study, "Joho Sangyo Ron" ("On knowledge industries"), published in 1963, he postulated that the 'electronic industries' (information, communication, education) would be just as pivotal for the structural transformation of the industrial society as the intermediary industries (transportation, heavy industry) were for the transition from the agricultural to the industrial society (Ito 1989: 13f.).

Umesao's approach stands in the tradition of the - later often criticised - paradigm of linear modernisation: social progress is seen as linear evolution from a 'lower' (traditional society) to a 'higher' (modern society) stage (see, e.g., Rostow 1960). At the same time, Umesao adapted the three-sector theory in which national economies are defined as the sum of the agricultural, industrial and service sectors (see, e.g., Fourastie 1954).

In the US, Machlup was the key figure in studying information society. He augmented the 'three sector model' with a fourth sector: the 'knowledge industry' (Machlup 1962). Machlup's study, together with Japanese publications (Ito 1989: 23), marks the beginning of information economy research, which drafts and tests indicators for the empirical evaluation of emerging information societies (Porat 1976; OECD 1981). Indicators such as the net product, gained by means of information activities as well as the number of information workers are used to analyse the emerging information society.

The political scientist Karl Deutsch defined information societies as national economies in which more than half of the work force is employed primarily in information-oriented occupations, and in which the net product of these activities is greater than half of the gross national product (GNP) (Deutsch 1983: 69f.). Other indicators of an information society are the expenditure coefficient, that is to say, the share of the expenditures of private households spent for information goods and services, as well as the cumulative index, in which, among 
other things, the circulation of nationally distributed newspapers per inhabitant, the number of computers per inhabitant, and the number of telephone calls are evaluated (Hensel 1990: 162).

However, basic assumptions underlying the information economy approach are still debatable (Löffelholz 1993: 114f., Kubicek 1995: 84f.). According to the OECD definition, all of the gainfully employed who produce, process and distribute information, or maintain the apparatus for its preparation and mediation are information workers. With this very broad definition, occupations (e.g., nursery school teachers, bookkeepers, physicists, forest rangers or restaurant proprietors) which are structurally and functionally quite heterogeneous can be subsumed under information work. However, statements about structural changes can hardly be based solely on the observation that the number of heterogeneous occupations is growing - in particular, because it is unclear, from what point on an activity combining various operations is to be classified as an information occupation.

A further objection to the information economy approach is that highly complex processes of structural change could neither be sufficiently differentiated nor even described to any acceptable degree of completeness by means of an indicator grid much more sensitive than that proposed in the studies mentioned. The limitation to technical and economic indicators characteristic of the information economy approach lures its proponents to a reductionistic argumentation: in functionally differentiated societies, social change never follows technically or economically determined rationalities alone.

\subsection{The Information Society as Post-Industrial Society}

In contrast to the economically deterministic information economy approach, the sociologist Daniel Bell proposed the analytical concept of a post-industrial society, in which social change is seen as a multidimensional process. In the course of this process, various 'axes' of organisation in industrial societies (economic sectors, vocational groups, fundamentals of technology, basic social principles) are so radically shifted that the result could well be called a postindustrial society.

The post-industrial society is founded on the growing importance of the information sector, as opposed to the production of goods, on production which is primarily dependent on information (rather than on raw materials and energy), as well as on a changed 'axial principle' (fundamental social orientation). In an industrial society, goods are produced primarily by machines and private property is held to be an axial principle - in a post-industrial society, acquiring and utilising information and knowledge play the key role. This is made possible by replacing intuitive decisions by algorithms, by 'intelligent technologies' based on computerised information processing. Theoretical knowledge becomes a guideline of social organisation, and the post-industrial society develops itself into a knowledge or rather, information society (Bell 1989: 112ff. 353).

The impetus for the transition to the 'information society', in Bell's opinion, is provided first and foremost by technical innovations (particularly in microelectronics) as well as the exponential expansion and differentiation of knowledge. The quantitative and qualitative growth of our knowledge and the technological and economic growth of the information sector stand, according to Bell, in a reciprocal relationship to one another, but are induced by other factors of social change - for example, by the increasing importance of the science system (Bell 1989: 179ff.). Seen in the political context of the 1970's, when social planning according to scientific methods was still held to be feasible, it is understandable that Bell assumed that scientifically well-founded decisions should gain greatly in influence against other means of social regulation.

A review of the introduction and spread of telematics (telecommunication and auto-informatics), however, shows that even the informatisation of society (which is held to be a basic trend) quite substantially follows the rules immanent in a market economy. Not the knowledge won, for example, by systematic technological assessment, but above all profit maximisation, competition, the pressure to adapt to new technologies and the respective national government as a focal point of individual economic interests determine the dynamics and the 
procedures for the 'information society' (Werle 1990; Kubicek/Berger 1990: 45ff.).

Soete recently suggested a return to the issues raised in the old information society debate', pointing to a shift, implicit in the notion of information society, to a post-industrial society, in which the largest part of new value added is being created in the non-industrial sectors of the economy. The growth of the tertiary (service) sector, and with that, what can be called the information service sector, is one of the most important economic and social phenomena of Europe's current industrial transformation (1996: 47). He stresses that it is essential to enlarge the debate on information society to the demand side and to look at those social factors that hinder the demand for new ICTbased products.

Bell's argumentation is interesting insofar as it combines the various concepts of postindustrial, service, information and even knowledge society in some kind of a 'march through the sectors' concept. Such a concept, however, also attracted a lot of criticism. Gershuny and Miles (1983), for example, have questioned Bell's de-industrialisation thesis. The continuous replacement of particular service activities by industrial products, according to them, can also be interpreted as a process of industrialisation of services. On the other hand, an 'information society', to some extent, also depends on the production of hardware and other technical equipment; therefore, we cannot characterise the 'information society' as a 'postindustrial society'.

Nor is the relationship between the concept of 'information society', on the one hand, and 'service society' on the other, as clear as is assumed by Bell. Although in many services the processing and exchange of information and knowledge is the core activity increasingly taking place through modern ICTs, this is hardly a criterion to distinguish between industrial and service societies. There are services mainly personal services - for which no ICTs are needed and at the same time, due to mechanisation and automation, industrial production is becoming more and more interpenetrated with processes of gathering, processing and transferring information. One can even speak of a kind of converging tendency between industrial production and particular service processes the more the manufacturing process becomes dematerialised. The distinction between manufacturing and services becomes more and more blurred as much of the value provided by the successful enterprise entails services.

From what has been said so far, we must draw the conclusion that the idea of a 'march through the sectors' (Lyon 1988, Miles 1988), as it has been developed by Bell and which most approaches analysing the emerging information or knowledge society are based on, must be rejected. Neither can we speak of the vanishing of the industrial society nor can we argue that 'information society' can be characterised as a 'post-industrial society' with technical knowledge as a new axial principle. Furthermore, to assume that information will become the leading sector about to supersede the industrial and the service sector, is also missing the point. What really characterises the current transformation process is the fact that all sectors and industries are increasingly interpenetrated by information work and that human work will occur more and more through the intermediary of ICTs.

Instead of arguing that information society' will replace industrial society, we can conclude that existing socio-economic structures will be transformed by processes of informatisation. This transformation process can be characterised more as an evolutionary than a revolutionary process. One can, of course, argue that in many ways all human societies have been information economies in that all economic activities depend upon human beings and their ability to bring information to bear on their tasks. In fact, all tasks to which human labour is applied inherently involve some measures of information processing. This might be in terms of: receiving instructions (communication); checking to see in what state the materials are (perception); performing calculations or other mental acts (transformation of information) (Miles and Robins 1994). This would mean that in some way all societies have been information societies.

There is no doubt that the argument has some truth in it. However, when we use the notion of an information or knowledge society, we are not talking about a historical universe. The term is used to characterise a new and unprecedented kind of social and economic for- 
mation (Miles and Robins 1994). The new, however, is not a totally new society but fundamental changes within the existing society; instead of distinguishing between an industrial and a post-industrial economy we had better distinguish between two forms of information or knowledge-based industrial, agrarian and service production (Castells 1997: 20).

\subsection{The Information Society as the Era of Post- Fordism}

This perspective describes the process of an emerging information economy in terms of the transformation from a socio-economic era called 'Fordism' to one referred to as 'postFordism'. This approach has a broad economic and political perspective, its main ideas were developed by the French 'Regulation School' (Aglietta 1976, see also Jessop 1991). This school characterises the current period as the 'crisis of Fordism'. The term 'Fordism' includes the economic system as well as the social and institutional framework that have structured capitalist economies since the late forties.

Fordism is associated with a growth model, which is based on the exploitation of economies of scale in the manufacturing of standardised goods and has mass production and mass consumption as its basic requirement. The Keynsian interventionist and welfare state is seen as the key institutional element that supports this economic structure.

The 1970s are seen as the turning point of economic development. Due to a number of reasons, including a productivity slowdown, changing market demands and market saturation, Fordism both as an economic system and as a social and institutional framework became unstable and had to be replaced by a new production regime, which was characterised as 'post-Fordism'. Privatisation, deregulation and a disintegration of the welfare state are seen as key elements of a 'post-Fordist' production regime. The following table contains a characterisation of the ideal types of 'Fordism' and 'postFordism'.

\begin{tabular}{|c|c|}
\hline Fordism & Post-Fordism \\
\hline $\begin{array}{l}\text { low technological inno- } \\
\text { vation }\end{array}$ & accelerated innovation \\
\hline $\begin{array}{l}\text { fixed product lines, } \\
\text { long runs }\end{array}$ & $\begin{array}{l}\text { high variety of product, } \\
\text { shorter runs }\end{array}$ \\
\hline mass marketing & $\begin{array}{l}\text { market diversification } \\
\text { and niche markets }\end{array}$ \\
\hline $\begin{array}{l}\text { steep hierarchy, vertical } \\
\text { chains of command }\end{array}$ & $\begin{array}{l}\text { flat hierarchy, more } \\
\text { lateral communication }\end{array}$ \\
\hline $\begin{array}{l}\text { mechanistic organisa- } \\
\text { tion }\end{array}$ & organismic organisation \\
\hline $\begin{array}{l}\text { vertical and horizontal } \\
\text { integration, central } \\
\text { planning }\end{array}$ & $\begin{array}{l}\text { autonomous profit } \\
\text { centres, network sys- } \\
\text { tems, internal markets } \\
\text { within firms; } \\
\text { outsourcing }\end{array}$ \\
\hline bureaucracy & $\begin{array}{l}\text { professionalism, entre- } \\
\text { preneurialism }\end{array}$ \\
\hline $\begin{array}{l}\text { mass unions, central- } \\
\text { ised wage-bargaining }\end{array}$ & $\begin{array}{l}\text { localised bargaining, } \\
\text { core and periphery } \\
\text { work force divided, no } \\
\text { corporation }\end{array}$ \\
\hline $\begin{array}{l}\text { unified class formation, } \\
\text { dualistic political sys- } \\
\text { tems }\end{array}$ & $\begin{array}{l}\text { pluralistic class forma- } \\
\text { tions, multi-party sys- } \\
\text { tems }\end{array}$ \\
\hline $\begin{array}{l}\text { institutionalised class } \\
\text { compromises }\end{array}$ & $\begin{array}{l}\text { fragmented political } \\
\text { markets }\end{array}$ \\
\hline $\begin{array}{l}\text { standardised forms of } \\
\text { welfare }\end{array}$ & $\begin{array}{l}\text { consumer choice in } \\
\text { welfare }\end{array}$ \\
\hline $\begin{array}{l}\text { prescribed 'courses' in } \\
\text { education }\end{array}$ & $\begin{array}{l}\text { credit transfers, modu- } \\
\text { larity, self guided in- } \\
\text { struction, 'independent' } \\
\text { study }\end{array}$ \\
\hline $\begin{array}{l}\text { standardised assessment } \\
\text { (O level) }\end{array}$ & $\begin{array}{l}\text { teacher-based assess- } \\
\text { ment (GCSE) or self } \\
\text { assessment }\end{array}$ \\
\hline $\begin{array}{l}\text { class parties, nation- } \\
\text { wide }\end{array}$ & $\begin{array}{l}\text { social movements, } \\
\text { multi-parties; regional } \\
\text { diversification }\end{array}$ \\
\hline
\end{tabular}

Table 1: Fordism - Post-Fordism.

Source: Rustin (1989, pp. 56-7).

At first, technology was not seen as an important factor in determining social and economic transformation. Subsequently, however, Roobeek (1987) and others have given more emphasis to the role of new technologies in the process of transformation to 'post-Fordism'. According to Roobeek, modern technologies can be seen as the main catalysts propelling the development of a 'post-Fordist' production regime. The fact that Roobeek and others have seen 'post-Fordism' in terms of the emergence 
of a 'new technological paradigm' has contributed to the critique of 'post-Fordism' being influenced by technological determinism. Furthermore, the fact that the concept of 'crisis' and historical shift' have been used in a very vague manner, has also been criticised. And the focus of the 'post-Fordist' approach is unclear; sometimes the object of research is reduced to the labour process and business organisation, although the French Regulation School has a much broader perspective including the economic system and even society as a whole.

\subsection{The "Information Society" as an "Informa- tised Industrial Society"}

Within the scope of the traditional concepts of industrial society, the means of production, in particular the technologies required, are seen as the central causes of social change. It is widely accepted that information and communications technologies, due to their multi-functionality, their network capabilities, the speed and breadth of their diffusion, have established themselves as base technologies. The introduction of these technologies would therefore mark the beginning of the informatisation of society, and is also known as the "Second Industrial Revolution" (Steinmüller 1981: 152f.): in a standing phrase, the automation of manual labour is now followed by the automation of brainwork. Informatisation can be defined as the adoption of information and communications technologies insofar as they have an impact on work practices. The emergence of an information society is reflected in the growing dissemination of information and communication technologies in all areas of social and individual life.

The decisive impetus for the spread of information and communications technologies, according to Beninger (1986) was a management crisis initiated by the Industrial Revolution. With industrialisation and the growing need to distribute goods quickly and over great distances, the demand for control technologies which could direct the exchange of goods by means of information processing, also grew. For this reason, according to Beninger (1986: 20), modern media systems, as well as a system of mass feedback-technologies, for example, marketing research and opinion research are allegedly promoting sales, arose within a century on the basis of existing technologies.

Besides Beninger's hypothesis, according to which the origins of the information society are rooted primarily in the interests of industry, there are also explanations, which put a 'technology-push' to the forefront. Nora and Minc (1979) argue that the penetration of all social spheres by modern ICTs is the key characteristic of the information society. Technology is seen as the driving force and all other aspects of society have to adjust. The technology push approach is also echoed in the very influential Bangemann Report: "Throughout the world", the report states, "information and communication technologies are generating a new industrial revolution already as significant and farreaching as those of the past" (High Level Group on the Information Society 1994: 3). In such an approach, technological development is seen as independent of society; it shapes society but is not reciprocally influenced. Rather, it exists outside society, but at the same time influences social change.

The 'technological push approach' is often based on the concept of 'heartland technologies' and in this concept, modern ICT is seen as the latest revolutionary heartland technology. A heartland technology, according to Perez (1983), is a technology which is employed across many production processes; it is typical of a heartland technology that its diffusion offers great economic benefits such as cost reduction, improvement of quality, and saving of time, which cause its wide and rapid application. Associated with the wide diffusion of a heartland technology are fundamental socioeconomic changes: new methods of production, new products, new organisation forms and work regulations or new skills. Modern ICTs are seen as a heartland technology because they revolutionise those production processes which have not been affected by former technological revolutions, as, for example, office work (Miles and Robins 1994: 9).

The 'technology push approach', which associates the development of the information society with a technical revolution of production, can only insufficiently comprehend the fundamental economic and social changes caused by this transformation process. The dynamics of this change cannot be revealed from 
the quantitative increase of applications of modern ICTs. It is important to analyse ICTs not as an exogenous source of impact, but as the fabric in which human activity is woven; we therefore have to stress the process-perspective of modern ICTs besides the inducing of new products (Castells 1997: 30f.).

In the last few years, according to Robins and Webster, there has been a decided step away from prioritising technology as the centrepiece of change and therefore also from the 'technology push approach'. "... nowadays the focus is on information - rather than information and communication technologies - as the key source of change" (1997: 3). Informatisation is no longer seen as a technological concept, but is used to highlight the penetration of information activities into all economic sectors and industries. In contrast, the role modern ICTs play in the transformation of society is regarded as a minor one when compared to the major part played by information. Information is becoming an important asset, as the economy is becoming more and more uncertain, which as we will argue later - is caused by increasing global competition.

\subsection{The "Information Society" as a "Knowledge Society"}

In the frame of reference of the 'knowledge society', the change in the basis of society's knowledge is emphasised. The coupling of science and techniques is held to be its most important characteristic, and in particular, the information and communication technologies are predestined to bring about this linkage. Three key developments deserve mention, when we talk about the development of a 'knowledge society':

- the enormous growth of knowledge

- the development of the computer as a knowledge-based machine

- the confluence of both of these into the cognitive-technical complexes of knowledge-based techniques and types of mechanised knowledge.

The formation of a mountain of information is in the first place the result of the exponential increase in the scientific forms of knowledge, knowledge of theory and of rules. In the second place we have to mention the rapid growth of knowledge in the non-scientific areas of administration, mass media, information services, and protection facilities. This, in combination with the increase in scientific knowledge, leads to the genesis of the massively expanding information sector of the 'knowledge industry'.

Furthermore, the information implosion, which, practically from the beginning, went hand in hand with the information explosion, contributed significantly to the formation of a mountain of information. By information implosion we mean the investment of information in a technical development or an industrial product but also the fact that the course of events, political decisions for example, is influenced by a greater amount of information than in earlier times. In contrast to the "scientification" which follows only gradually and incompletely, as a result of the exponential growth of knowledge, the information implosion leads to an immediate and far-reaching informatisation of society.

Besides pointing to the immense growth of knowledge, the proponents of the 'knowledge society' concept lay emphasis on the singular importance of the computer, which has become a knowledge-based machine. Almost unanimously, the various authors make reference to the computer. But the computer did not become a 'knowledge machine' in its original but only with its transformation into a 'knowledge-based system', which incorporated the knowledge bases and conclusions of experts. Although the pretentious programme for the development of autonomous expert systems must be conceded to be a failure (Malsch and Seltz 1987), we should nonetheless not overlook the important fact, that programming techniques and the products of the 'artificial intelligence technology' have already been integrated into modern software. In analogy to the self-reference of mechanical engineering production, we have, in the case of the software, not reproduced the knowledge itself, but the manner of working with the objects and tools of knowledge in the computer programmes. When the formalisation and mechanisation of a field of knowledge has made great progress, this manner of working can be emulated.

The knowledge society is characterised by the fact that all of its functional systems - and 
not merely a subsystem - are bound to a knowledge base in their basic manner of operation. This knowledge base establishes itself within the structure of the elements determining the system's operation and thereby changes their quality. A knowledge society is not only characterised by the fact that its members enjoy, on average, a longer and more professional education, that more products are provided with builtin intelligence, and that its organizations transform themselves into knowledge-based entities. The importance of knowledge, intelligence, and expert opinion changes the traditional forms of operations based on a division of labour. Until now, the fact that science was solely responsible for the production, evaluation, canonisation and revision of the knowledge it generated was virtually a characteristic of modernity (Luhmann 1990; Stichweh 1997). Other functional systems, such as politics, law, education, health, etc., incorporated new knowledge by means of intermediary processes, such as asking political advisors, experts' hearings, teaching, combining medical research and practice in university clinics, etc., and formulated their demands on science.

Today, however, we can observe a weakening of this division of labour as a result of the spread of multiple "centres of expert opinion". Knowledge is only one form of organised information among others. These are, for example, functioning technologies, expert opinion, intelligence, implicit knowledge, organised systems of symbols, organisational knowledge, and management know-how. Science is no longer able to control the production and use of specialised expert opinion, which is generated in 'foreign' contexts. But above all, the rate of the revision of knowledge has accelerated just because of this polycentric production of knowledge, so that the tedious detour via the conventional scientific system would be selfdefeating. It is striking, therefore, that expert opinion in management and new concepts for business administration are no longer developed in economics or in the theory of organisation or management, but rather either in reflected practice, or in hybrid systems of the organisational or management consultants interested in theory (Peters 1994; Senge 1990; Womack, Jones and Roos 1990).

\subsection{The "Information Society" as a "Learning Society"}

Castells is rather critical, attaching such high importance to information as a key factor in social transformation. "What characterises the current technological revolution," he argues, "is not the centrality of knowledge and information, but the application of such knowledge and information to knowledge generation and information processing/communication devices, in a cumulative feedback loop between innovation and the use of innovation" (1997: 32). It is the immediate feedback between knowledge generation and knowledge application through learning by doing and learning by interacting that, according to Castells, becomes the key aspect of the 'information society'.

We can speak of some kind of a spiral movement: Through learning by doing, new knowledge occurs, which is directly applied in the production process and therefore leads to an acceleration of the innovation process. Innovation, we can conclude, becomes a normal part of work, which creates new opportunities for learning. Such an understanding needs a new learning concept. We have to reject transfer models, which isolate knowledge from practice, and develop a view of learning as social construction, putting knowledge back into the contexts in which it has meaning (Brown and Duguid 1991: 47). As the spiral movement described is at the very core of individual and organisational learning, it might be even more appropriate, instead of using the notion of information society, to talk about a 'learning economy and society' (Lundvall and Johnson 1993).

Learning takes place not only on the individual level but also through firms and organisations, on to inter-firm and inter-organisation learning, cross institutional learning, and on to the whole system - the learning economy (Archibugi, Howells, and Michie 1998: 6). Mathews (1996) differentiates between three orders of learning. First order learning is learning which takes place within a company, for example through interaction between different functions or teams. Second-order learning takes place when various companies exchange information and knowledge through the establishment of production or co-operation networks. 
Third order learning includes not only companies but also private and public organisations as partners in the process of knowledge and information exchange (Alasoini 1998: 1).

The learning process involves a clear interaction and collective dimension, it must be interpreted more as a dialogue between a number of centres of innovation of equal standing than as a one-way transfer of knowledge from one actor to others. It is argued that for the effectiveness of learning processes it is vital that all actors on the three different levels follow the same operating principles. In this respect Mathews (1996) uses the term holonic organisational architecture' while Riegler (1998) speaks of 'the principle of structural correspondence'.

The concept of a learning economy and society is still disputed. As Archibugi et al. (1998: 6) argue: " ...(It is hard) to ascribe collections of firms, organisations and institutions as having a single, clear cognitive process, involving both a decision-making and memory function. The notion that what is learnt will be exactly the same for each individual, firm, organisation and institution is difficult to accept."

\subsection{Conclusion}

We have presented a number of theoretical concepts, all of which analyse the emerging information economy or society, however, each from a very different perspective. Although each approach sheds some light on the significance of information and information technology in the current transformation process, no single one is capable of encompassing all the different aspects of change. It is, of course, difficult to separate the various aspects from each other clearly; they overlap to some extent and some convergence can also be seen. However, whatever attempts are made to develop a comprehensive approach, we are still far away from any general theory of information economy or society.

Do the various approaches to information society have anything in common? Obviously all proponents of information or knowledge society agree that the emerging new society will bring about change at the core of society as it initiates a new mode of production. It changes the very source of wealth-creation and the governing factors in production. Labour and capital, the central variables of the industrial society, are replaced by information and knowledge as the main variables in the new emerging society. But, as Castells argues, what may be even more important is the establishment of a new mechanism of immediately applying new information and knowledge in the production process. Here the focus is on learning.

Despite the widespread agreement that the emerging information society will cause major social changes, there is still a debate on whether we can speak of information society as a totally new society. This argument is based on a more general tendency to look at historical transformation in terms of the shift from one 'phase' or 'stage' of development to another. Often the socio-economic transformation is seen as a movement from bad times to a more promising and challenging future (Miles and Robins 1994: 15).

This linear perspective, of course, is very simplistic; it overestimates change and does not recognise continuities over time. Certain new tendencies in the present are seen as key elements of the future, while countervailing and divergent processes are not taken into account: "Rather than seeing economic and social change in this linear way, a more appropriate metaphor might be one of cumulative developments in which the new developments form as 'layers' across the old, with new and old always co-existing" (Miles and Robins 1994: 17). From this we can conclude that the increased use of information and knowledge in production does not necessarily include a fundamental change of the character of our existing market economy. It seems to be more appropriate to talk about a new information and knowledge-based industrial and service production.

The role of ICTs in the current transformation process is also highly controversial. In a research area which is mainly concerned with new technologies there is always a danger of falling into a perspective of technological determinism. But while some scientists and politicians still argue that ICT is the driving force behind the emerging information society others are trying to avoid such argumentation. However, though the social is taken into account, this is often done in a more functionalist way: 
The argument then is that techno-economic change brings about new social structures and institutions.

Some researchers, more conscious of the temptation of technological determinism, point to global competition, changing consumer demands or deregulation as important factors that cause the transformation process. Still, modern ICTs are given a major role in the transformation process. They can, it is argued, support the development of new social structures, given a push by other drivers of change.

\section{Understanding Information and Knowl- edge}

As the former discussion has demonstrated the concepts of information and knowledge society are not very clearly distinguished from each other. Therefore it becomes necessary to acquire a better understanding of what is meant by 'information' compared to 'data' or 'knowledge'. In the following we will try to differentiate more clearly between the three concepts. Data are, according to Bohn, "what comes directly from sensors, reporting on the measured level of some variables" (1994: 61). They are "events or entities represented in some symbolic form and capable of being processed" (Earl 1996: 38).

Only when data have been organised do they become information. We can define information as "data that have been organised or given structure - that is, placed in context - and thus endowed with meaning" (Glazer 1991). Information therefore includes a process of manipulating, re-presenting and interpreting data. The aim of developing information is to reduce uncertainty or ignorance, give surprises or insights and allow decision-making (Earl 1996: 13).

Information and knowledge are distinct insofar as it takes knowledge to produce valid and useful material and to be able to interpret this material (Miles et al. 1995: 16). While information, according to Bohn, tells the current or past status of some parts of the production system, "knowledge allows the making of predictions, causal associations, or prescriptive decisions about what to do" (1995: 62). It is important to understand knowledge as an active process; it involves the ability to interpret data. It is not just the content of a data base (Miles et al. 1995: 16). The tacit aspect of knowledge is "linked to the fact that production technology is about doing things, not only about knowing things in the form of an abstract (scientific) principle. Operating know-how is something very different and is much less transmissible" (Cohendet and Llerena 1997).

Taking up the idea that knowledge exists in different forms, Earl (1996) suggests differentiating between three aspects of knowledge: science (which may include accepted law, theory, and procedure), judgement (which may include policy rules, probabilistic parameters, and heuristics), and experience (which is no more than transactional, historical, and observational data to be subjected to scientific analysis or judgement preference and also to be a base for building new science and judgement). The author speaks about a hierarchy of knowledge: experience can be characterised as potential knowledge, judgement as workable knowledge and science as accepted knowledge. This means that each ascending level represents an increasing amount of structure, certainty, and validation.

Earl associates the three different levels of knowledge with different categories of learning. "Experience requires action and memory, judgement requires analysis and sensing, whilst science requires formulation and consensus (Earl 1996: 41). He also postulates the hierarchy of knowledge to be synonymous with the distinctions between data, information, and knowledge. "The lowest level is the equivalent of transaction data (and transaction processing systems). The middle level is the equivalent of information in the classical sense of reducing uncertainty to make decisions (and thus equivalent also to decision support systems). The highest level is knowledge where the user is constrained only by its availability or the intellect to exploit it (and thus approximate to the classical expert system or what some call intelligent knowledge-based systems)" (Earl 1996: 41). By overlapping the two taxonomies a better understanding of the differences between data, information, and knowledge can be reached as the following figure can demonstrate: 


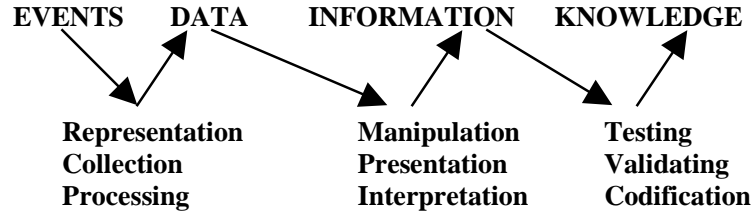

Figure 1: Towards conceptualizing knowledge. Source: Earl, M.J. (1996).

\section{Perspectives on Information Technolo- gy}

Information technology (IT) or information and communication technology (ICT), as it is also termed, covers a remarkable range of technologies. There are no established methods for defining ICTs. This is not surprising, as the term can be used to cover everything from the mobile phone to the personal computer, from satellite broadcasting to computer-aided design and computer integrated manufacturing, from the video camera to the supercomputer and from the pocket calculator to the colour TV. Many attempts have been made to define information technologies prior to measuring their extent and impact. Here we will not add another definition.

Information technologies have developed out of the convergence of the (microelectronic) computer with telecommunications, which has removed the long-standing distinction between the processing of information and knowledge and its communication. To make orientation easier Miles et al. (1995: 24) have differentiated between core technologies and integrating technologies. Each of the core technologies, according to their definition, performs one of the five basic information handling functions: production or collection of data, storage and retrieval of data, data processing, data transmission, or the display or presentation of data. Integrating technologies, on the other hand, bind together several core technologies as, for example, multimedia communication.

We have good reasons not to discuss the technology and development trends in great detail (Miles et al. 1995), as it is not the given and 'unchangeable nature' of ICT itself, but the functions it has to perform that determine both the nature and extent of benefits which can be gained from this technology. In this respect, Somogyi and Galliers have identified changes in the functions ICTs have performed and are performing nowadays. "The very expression describing the activity that IT is conducting has changed from the original 'data processing' through 'management information' to the more information processing" (1997: 9). In concrete situations, various functions of ICTs can become relevant at the same time. The function that becomes relevant may vary with the organisation's purpose for using the technology and also how the technology has been used within the organisation.

Here we will discuss the following dimensions of modern ICTs: They can function as tools, as automation technologies, as control devices, as organisation technologies or strategies, as a medium which connects machines and people with each other and as a process to be developed. Finally, we will discuss the concept of technological practice.

\subsection{ICTs as Tools}

Like all other technologies, ICTs can first be characterised as tools to work with (Eason 1988). From this perspective technology is a machine or an apparatus, a simple artefact; it is visible and tangible. The tool approach is based on a materialistic view of technology. The introduction of modern ICTs, then, refers to single sub-processes or tasks only. As tools, modern ICTs are intended to support people in their work; the aim is to give individuals some advantages in pursuing their tasks - to enhance the task performance, for example, or to enable people to work more rapidly and more exactly. One can argue, however, that only when the mini-computer was developed in the beginning of the 1970s, could ICTs serve the tool function; the mini was equipped for real work (Somogyi and Galliers 1997: 13). While the huge mainframes represent automation technology, minis and later on microcomputers can become useful tools in the hands of workers.

Eason gives some examples of modern ICTs as a tool: "Word processing enables the unskilled typist to produce good quality outputs because there are no messy errors corrected on the paper. An integrated work station gives the 
full power of a publishing house to a single operator; to present type in many forms, integrate it with tables and diagrams, vary size of the characters, etc. Planning with network control software means it is possible to vary an element in the plan and examine its impact on the whole plan. Similarly, a spreadsheet enables the financial planner to change a single estimate and quickly see its implication for overall costs. Not only does computer-aided design enable designers to build a three-dimensional model that can be examined from any angle but it makes it possible to test the effect of changing an element of the structure" (1988: 19).

According to Eason, modern ICTs can be seen as hand tools. However, the computer or the microprocessor only indirectly manipulates the material conditions of the product; in the first place, it syntactically manipulates its internal state: Data are processed and new data are created. Therefore, the computer is characterised as 'brain technology' (Krämer 1989). The fact that ICTs can duplicate and process all symbolic artefacts and that they can easily be re-programmed makes them a very flexible and unique tool.

In the beginning, computers were introduced to facilitate routine tasks such as administrative data processing, accounting and statistical analysis. But later on, computers could also be used to assist in design and planning and to support managers in their decisionmaking, making it easier to rehearse quickly various alternative solutions.

Modern ICTs are doubtless very powerful tools, as they can store a huge amount of information and process it within a very short time. Modern ICTs increase an organisation's memory dramatically, which can be defined as stored information from an organisation's history that can be brought to bear on present decisions (Walsh and Ungson 1991: 61). Sometimes it would not even be possible to conduct specific tasks without ICTs as a powerful tool. For example, simulations make is possible to manage great complexity, which would not be possible without modern ICTs. From what has been said so far, one can draw the conclusion that modern ICTs as a tool can make companies more competitive not only regarding costs and prices but also time and quality.

\subsection{ICTs as Control Device and Automation Technology}

Modern ICTs can become a powerful tool in the hands of the workers supporting them in their work but ICTs can also be used as a control device by management. Some academics even argue that the development and broad diffusion of ICTs can be traced back to the 'crisis of control' in the production process, which occurred already over a century ago (Beninger 1986). Nowadays, due to modern ICTs, it is becoming possible to monitor the work process and individual work behaviour directly and to control work progress continuously. Therefore, when needed, the management can immediately intervene in the work process and demand a change in the work process or in work behaviour.

However, the aspect of control is not only related to individual behaviour but to the whole work and business process. When more and more routine operations become automated, or at least supported by computer systems, effective control of interrelated operations is not possible, however, on the basis of stand-alone systems. By the end of the 1960s, it became clear that for control purposes it was necessary to develop an idea of a set of information which could be used independent of its application. "It was therefore important to de-couple data from the basic processes. The basic data could then be used for information and control purposes in new kinds of systems" (Somogyi and Galliers 1997: 16). The advent of databases and more sophisticated and powerful mainframe computers gave rise to the idea of developing MIS (management information systems) as a key control device in the hands of top management.

Ambitious attempts to develop 'Management Information Systems' that integrate and aggregate the information from all business functions and processes, so that top management should have access to the latest information on any action in the whole enterprise at any time, have failed. Obviously, this cannot be explained by technical restrictions, such as too little storage capacity; the critical problem seems to be that of developing data models of all business processes which apply to the different tasks and views of managers on different 
levels and in different functions (Kubicek 1995: 77).

The idea of integrated MISs seems to have presented an unrealistic goal for several reasons:

- difficulties in deciding about the data needed for an efficient control system

- unclear use for decision-making

- backward orientation of data.

The MIS activity, as Keen and Morton (1978) argue, was not really a focus on management information but on information management.

ICTs are also characterised as automation technologies. Actually, computers were first used to automate the routine clerical work of large administrative departments. They make it possible to transfer the knowledge of skilled workers into machinery and thereby to eliminate human labour. "The most important impact of new ICTs," according to Soete, is that "they move the border between tacit and codified knowledge. They make it technically possible and economically attractive to codify kinds of knowledge which so far have remained in tacit forms" (1996: 49). Codification of knowledge leads to the automation of production functions and processes. Calculable operations are taken over by machines and they can, for example, be integrated into process-overlapping computerintegrated manufacturing (CIM) architectures.

To codify tacit knowledge is often difficult, because it is complex and it is especially difficult and costly to codify knowledge when the reality it refers to or on which it operates is changing rapidly (Ernst and Lundvall 1997: 8). So far, automating human skills has proved to be economically successful only in relation to relatively simple tasks, but increasingly attempts are also being made to transfer expert knowledge into data and expert systems. The greater the capability of modern ICTs to perform production functions on their own the more human labour will become redundant.

Ernst and Lundvall, however, also argue that the elimination of human labour is only one aspect of the automation process; the codification of tacit knowledge and its transfer into modern ICTs also creates a demand for new activities and skills. "The very growth in the amount of information which is made accessible to economic agents increases the demand for skills in selecting and using information intelligently (1997: 28). Modern ICTs, although they depend on codified knowledge, at the same time create new demands for tacit knowledge.

The use of modern ICTs as automation technology supports the change from traditional services to self-servicing (Gershuny 1983) where the customer does what in traditional services paid employees would have done. Home-banking or home-shopping are typical examples of self-servicing.

\subsection{ICTs as Organisation Technologies}

Furthermore, ICTs are conceived as organisation technologies. They become an objectivation of the work organisation as they incorporate elements of social relations between various actors. As such they integrate work processes conducted by human beings and machine processes into one total process (Brandt et al. 1978). "The growing convergence of technologies, especially in the area of micro-electronics, offers a great technological potential to integrate or merge functions, processes and divisions" (Tulder and Junne 1988: 82f.).

Particularly when it was stated that technological systems should become more userfriendly, the wide-ranging organisational effects of IT systems became more visible. During the 1980s, several researchers developed farreaching ideas about letting systems evolve within organisational environments, at the same time challenging the traditional engineering view of system development. It was pointed out that computerised information systems were, so to speak "one side of a two-sided coin, the other side being the human organisation where these systems perform" (Somogyi and Galliers 1997: 23).

The fact that modern ICTs can be perceived as organisation technologies is taken up by the concept of 'systemic rationalisation'. While traditional models of rationalisation can be characterised as precise and applied to single functions, the systemic form of rationalisation aims at restructuring a plurality of functions, processes and departments and even includes inter-organisational relationships (Baethge and Oberbeck 1986, Altmann et al. 1986). However, forms of organisational restructuring are not designated as 'systemic' primarily because 
they include database network systems which can be used by management for long-range strategic planning and for the purpose of control (Wittke 1990: 23f.). Furthermore, systemic rationalisation does not mean the restructuring of an organisation as effectively as possible in relation to a specific goal. What is new concerning the 'systemic type of rationalisation' is that it comprises an enlarged perspective of restructuring affecting the means and ends simultaneously.

By abstracting from the specificity of a single work process, the computer can systematically integrate various work processes. The real advantage of ICTs, it can be argued, is not that they improve existing processes, but that they allow companies to follow new working methods due to their potential to integrate functions and processes. Indeed, due to their integration potential, ICT's in principle allow everything to go faster: faster product development, faster production, faster delivery, faster service. The integration function of modern ICTs was first realised through large mainframe-based technology concepts. In this case, access to the database is regulated centrally. Users can no longer decide how to proceed in their work process; instead, the sequence of their actions is unequivocally prescribed by the technology, as they are integrated in an automated production process.

Technological integration may also cross company boundaries as, for example, in just-intime (JIT) systems. The integrative potential of new ICTs is intensively used in the car industry. Concepts of logistics for planning, manufacturing and supply processes have been drawn to the centre of management strategies. Due to the set-up of a computer-based network system, the technical integration and control of all information and manufacturing processes relevant to such a complex product as a car is possible. Thereby the undesirable risk of stoppage, blocking and waiting periods among various co-operating departments but also among various organisations can be reduced to a minimum, although they cannot be eliminated totally (Doleschal 1991: 254). Modern ICTs thus become the core of systemic forms of business restructuring. Instead of focusing on single workplaces, a holistic approach is applied, which means that the business organisation as a whole and particularly its governance structures are the target of restructuring.

Again, high targets of integrating business processes associated with Computer Integrated Manufacturing cannot be reached. For this various reasons can be given, including "the impossibility of developing a comprehensive universal data model, the problem of data maintenance for such a big system, and last but not least the problem of vulnerability of such highly integrated and tightly coupled system" (Kubicek 1995: 78). A more sceptical perspective on the nowadays very popular Inter-organisational Information Systems can be based on similar arguments.

Often ICTs are interpreted in a more dynamic way, not as organisation technologies but as a strategy to structure production processes. To stress this strategic aspect one can use the term 'technisation' (Barley 1986). Technisation means that social relationships become incorporated into technologies; then technologies govern the reproduction of social relationships. We can also speak of ICTs as configurations, this term emphasises that developing technologies, setting goals, and developing business strategies are processes which take place simultaneously and have reciprocal influence. Technisation, however, is only one strategy to structure production processes and to secure reproduction of social relationships; the establishment of organisation rules and norms can be seen as an alternative. But in general technisation and organisation only form two aspects of one and the same restructuring process.

Besides technisation and organising, we can identify enculturation as a third strategy to stabilise social relationships in work. This indirect way of influencing workers to continue existing forms of co-operation becomes particularly important in decentralised organisation structures in which agency is to a great extent freed from organisation norms and the dictating control of machine pace and in which selforganisation and direct co-ordination dominates. In such a structure there is always the risk that organisation members pursue departmental or subgroup aims and interests without taking the overall goal of the whole company into account. To establish a 'strong' business culture is seen as a possible strategy to socially integrate workers, to make them share the overall 
values and to see the "world with the eyes of the company" (Berger 1993: 16).

Common values are seen as the core of business culture. The aim of creating a strong business culture is in the first place to commit workers to the company; they should identify themselves with the company and see the company's aim as supporting their own interests. Building up trust relationships may be seen as the most important function of a strong business culture, but the intention is also to give an organisation a clear and coherent identity.

\subsection{Connectivity and the Media Function of ICTS}

The fact that computers and other ICT devices can be linked to each other can be characterised as connectivity. Real time connectivity is of particular importance; as a consequence of this, information can be distributed to various locations as it is created. We can conceive of modern ICTs as media that make various types of interaction and communication possible: machine-machine interaction, man-machine interaction and particularly man-man interaction.

The media perspective of ICTs becomes important, since more and more communication within and between companies is technically mediated. The role of ICTs as media is seen as enabling, facilitating or supporting information flows. The increased interest in problems of interconnectivity and information exchange in different forms and at different places is related to the development of telecommunication. Concerning the media function, ICTs change from an inwardly oriented technology forming islands of information and automation to an outwardly oriented technology supporting the formation of networks electronically.

When in the beginning of the 1980s 'personal computers' appeared on the market, the need for connectivity soon became obvious. The small dispersed machines were unlikely to be used effectively without a connection between them. The new focus of development in ICTs changed from computer technology to telecommunication. Separate technologies such as telephony, telecommunication office equipment and computer started to converge.

The media perspective is dealing primarily with communication that is not formalised.
Here the focus is not upon the capability of modern ICTs to substitute for tacit knowledge; from this perspective the emphasis is on their potential to reinforce human interaction and interactive learning, as Ernst and Lundvall argue, and on how they can support and mobilise tacit knowledge. "E-mail systems connecting agents sharing common local codes and frameworks of understanding can have this effect and broad access to data and information can further the development of common perspectives and objectives for the firm. Multimedia exchange may be helpful in transferring elements of tacit knowledge, for instance, by using combinations of voice and picture in an interactive mode" (1997: 28).

Modern ICTs are specific insofar as it is a communication device that bridges both time and space. Electronic communication technologies are enablers of changed forms by offering capabilities to overcome constraints on time and distance, key barriers around which organisation forms have traditionally been designed (Fulk and deSantis 1995: 337). By increasing peoples' accessibility to the work environment from home, and by redefining how employees can perform their duties across time-space boundaries modern ICTs are changing the traditional notion of a workplace (Sahay 1997: 248). In this respect telehomework is a good example.

Connectivity means that modern ICTs can form a platform for people to work collectively, they are developing as a collective tool (Baukrowitz 1996). In the beginning connectivity was confined to information exchange on the basis of computer to computer communication. But soon technologies developed that solved the problem of interconnecting large numbers of computers. We can here distinguish two different strategies: one which integrates the single computer into a centralised control system; the computer is then reduced to an output device and the other, in which all computers are 'equally entitled' and can interact directly among each other.

$\mathrm{R} \& \mathrm{D}$ and manufacturing bases dispersed globally may be connected with each other as well as with a central corporate file through the database network system. In this system researchers may interact with each other globally for discussion and consultation through elec- 
tronic mail. Designers may retrieve information from the central file about the availability of parts with derived specification for product development. Any engineering change occurring at a certain factory is fed back and incorporated into the original design stored in the central file and made available to any factory which uses the same global design (Aoki 1989: 18).

In the case of a decentralised workgroup computing model, jointly working on a complex task and directly co-ordinating reciprocal sub-processes will be possible. For example, workers, even if they are spatially separated, can jointly develop a new product or a new market strategy. ICTs are also used as a collective tool when a maintenance problem cannot be solved on the spot by the service technician responsible and he needs to ask specialists working somewhere else in the company for support. Co-ordination in electronic space is easier because the medium allows exchange of information and decision-making without copresence of participants. Jointly utilised artefacts, such as electronic documents, support cooperative work processes; a terrain is created for collective activities on the basis of interrelations between previously segregated actors. In all these cases, the aim of the system development is not to replicate technically whole work processes but to support collective work behaviour through a collective tool and access to information. However, as Wagner argues, coordination by way of new electronic media also involves the risk of misunderstanding and deception (1994: 34ff.).

For technology as a medium the following aspects are particularly important:

- the dramatic increase in the speed of communication, with high volumes of data moving from one location to another at rates unimaginable even a decade ago

- a sharp rise in communication bandwidth, with more information of multi-frequencies travelling at the same time down a common line

- the possibility of combining text, voice, video, data, and/or graphics within a multimedia communication system (Fulk and deSantis 1995)

- increasing mobility as connected ICT devices can be made small enough to be car- ried around. Their use is not limited to certain fixed locations (Lillrank et al. 1996).

One of the major impacts of modern ICTs as a medium is a further acceleration of the innovation process, as knowledge can easily be distributed. Furthermore, ICTs provide workers with a technical infrastructure on the basis of which they can continuously reshape their relationships with each other and also with machines. In some way we can argue that modern ICTs can replace organisation rules. Their function is to create stable relationships between people and between people and machines to secure continuous production. However, in a technical network, working people can continuously produce, reproduce and also change their relationships at the same time. There are, however, limits for modern ICTs to function as a medium that connects workers. The exchange of distance-sensitive knowledge, for example, still needs face-to-face contacts.

The latest trend concerning the media perspective is the integration of company internal digital information systems into a public information structure. Two technological developments are important here: interactive multimedia telecommunication applications on the one hand, and the use of the Internet for commercial purposes, including the development of new services, on the other hand. From the viewpoint of companies, the Internet offers an interesting platform for advertising their products and services. At the same time, a great demand for new information and communication services is developing. The disadvantage of the Internet so far is that the problem of protecting access to the companies' internal information systems does not yet appear to have been solved. The actual answer to this problem can be seen in Intranets, which are company internal nets on the basis of the Internet. They use the services of the Internet but at the same time they are protected against the public like private nets. We can expect that, in future, interactive multimedia applications will be developed which will support tele co-operation within companies, co-operation within supplier networks and increasingly communication and co-operation with customers. 


\subsection{ICTs as a Process to Be Developed and the Social Shaping Approach}

It is because of the great flexibility potential of modern ICTs that Castells talks about new ICTs as a process: "New information technologies" as he argues, "are not simply tools to be applied but processes to be developed" (1997: 32). Computing systems are typically developed and extended over a long time period of years (Kling 1987). This on the one hand means that software programmes can be improved and optimised but it also means that the programmes can be extended and new connections can be created and integrated.

If ICTs are seen as a process to be developed, Castells continues, then "users and doers may become the same. Thus users can take control of technology as in the case of the Internet.... It follows a close relationship between the social processes of creating and manipulating symbols ... and the capacity to produce and distribute services" (ibid. 32). While producing things or providing services, people simultaneously develop their technology. "For the first time in history", Castells continues to argue, "the human mind is a direct productive force not just a decisive element of the production system" (ibid. 32).

The fact that Castells conceptualises ICTs as a process characterises him as a representative of the social 'shaping approach'. This approach has developed out of a confrontation with the 'technological determinism' approach. Technological determinism not only assumes that technology development takes place outside society, that it is socially exogenous and follows an inherent logic, but it also presupposes that the technological artefacts determine the social consequences of their application.

The criticism of the 'social shaping approach' relates to both aspects of technological determinism (Wyatt 1998):

(1) It is taking up the argument that technical artefacts are 'neutral'; that they themselves do not determine the social. Contrary to technological determinism, the 'technology as neutral' concept does not assume that technologies have straightforward social effects, it therefore leaves space for human choice and intervention. According to the 'social shaping approach', there are always options to decide differently. The 'technology as neutral' approach, however, only considers the second part of the 'technological determinism' argument.

(2) The 'social shaping' approach also argues that technology itself is not neutral. Technological development according to this approach takes place within society; it is shaped by social, ecological and political factors. Furthermore, new technologies do not develop according to an inherent technological logic, they do not follow a predetermined development path but are constructed by human beings and influenced by their needs and interests.

Wyatt has nicely summarised the main aspects of the social shaping approach. Therefore, we will quote her at greater length:

"Technologies are social constructions, the outcome of negotiations between relevant social groups. To explain technological developments we need to identify who is involved and what their interests are. In any innovative effort, actors form alliances. A project often has a certain interpretative flexibility when there exist competing meanings. The selection of one of many possible solutions is also a social process. Often there is a key actor/entrepreneur who is instrumental in enrolling other actors and defining the scope of the technological frame. A successful mobilisation of arguments, interests or resources may result in closure; the artefact becomes stable and enters a wider world. But users of technical artefacts and systems also possess a degree of what could be described as interpretative flexibility, what I have termed earlier as malleability. New artefacts may or may not work, and may or may not be used. Some might fail or be used in unforeseen ways. If the technology fits within the technological frame of its wider community of users, it might acquire momentum. In this way, successful technologies give the appearance of autonomy" (Wyatt 1998: 17).

Although Castells can be seen as a representative of the 'social shaping approach', he distinguishes himself from the traditional concept insofar as he does not differentiate between the process of technology generation and the process of technology application. Instead, he emphatically stresses both generation and application of technology being one and the same process. While applying ICTs users also develop the technology; not only the technology, as we will argue later, but whole technological practices. 
Kling (1987) stresses the conflict element in this development process. Participants in this process include users, system developers, the senior management of the company, and any other individuals or groups who are affected by the computer-based information system. Some of them are interested in the development process because it can result in leverage such as increased control, speed, discretion over work or bargaining power, while others will oppose specific computing arrangements, as they fear to lose control and bargaining power. They will try to push alternative systems, which serve their interests better.

From a process perspective, modern ICTs can be described as 'configurations' (Fleck 1993) which are shaped by social actors taking into account the particular requirements of the application situation. The process perspective identifies modern ICTs as social facts insofar as they are the products of previous social actions, but it does not take into account that they can also exert constraints on social actors; they cannot be changed voluntarily by single actors.

\begin{tabular}{|l|l|l|}
\hline metaphor & \multicolumn{1}{|c|}{ function } & \multicolumn{1}{|c|}{ aim } \\
\hline tool & $\begin{array}{l}\text { support work } \\
\text { process }\end{array}$ & $\begin{array}{l}\text { increase quality, } \\
\text { speed up work } \\
\text { process, cope } \\
\text { with increased } \\
\text { complexity }\end{array}$ \\
\hline $\begin{array}{l}\text { automati- } \\
\text { on tech- } \\
\text { nology }\end{array}$ & $\begin{array}{l}\text { elimination of } \\
\text { human labour }\end{array}$ & costs cutting \\
\hline $\begin{array}{l}\text { control } \\
\text { instrument }\end{array}$ & $\begin{array}{l}\text { monitoring } \\
\text { and steering } \\
\text { work process }\end{array}$ & $\begin{array}{l}\text { adjustment to } \\
\text { changes, avoid- } \\
\text { ing defects }\end{array}$ \\
\hline $\begin{array}{l}\text { organisa- } \\
\text { tion tech- } \\
\text { nology }\end{array}$ & $\begin{array}{l}\text { co-ordination } \\
\text { of work } \\
\text { processes }\end{array}$ & $\begin{array}{l}\text { transparency, } \\
\text { organisational } \\
\text { flexibility }\end{array}$ \\
\hline medium & $\begin{array}{l}\text { setting up of } \\
\text { technical } \\
\text { connections } \\
\text { for communi- } \\
\text { cation }\end{array}$ & $\begin{array}{l}\text { quick and inten- } \\
\text { sive exchange of } \\
\text { information and } \\
\text { knowledge }\end{array}$ \\
\hline process & $\begin{array}{l}\text { improve in- } \\
\text { formation } \\
\text { system }\end{array}$ & $\begin{array}{l}\text { continuous } \\
\text { learning }\end{array}$ \\
\hline
\end{tabular}

Table 2: Various perspectives of ICTs
Wyatt has criticised the social shaping approach in a very similar way. "In the enthusiasm to provide evidence to challenge widely held notions of the inevitability and naturalness of technical developments ... questions about the way in which these technical developments become part of the world in which we live, and subsequently condition or even structure our daily activities have been neglected.... Also, in stressing the social nature of the process of technical design and choice, the notion that 'anything is possible' has taken hold" (1998: 18).

\subsection{The Concept of Technological Practices}

ICTs, we can conclude, can be understood both as process and as structure. This means that there are two different research perspectives that lead to very controversial results. On the one hand it is assumed, that ICTs as a technical artefact will determine work processes to a great extent, while on the other hand the need to develope the technology is stressed. This also means that the use of ICTs does not determine the work process but this is open for deliberate design. The question then arises how to integrate the process and structure approach to avoid such controversial research results.

In a general 'theory of structuration' Giddens $(1979,1993)$ has made the attempt to resolve the dualistic grouping of objective conditions and subjective action and interaction and to integrate the actor and structure perspective in one theoretical framework by introducing the concept of 'social practices'. His particular interest is related to the question of how to explain the recursive character of social practices. According to Giddens, agents and structures represent a duality, they are not independent sets of phenomena, but a dialectic relationship exists between them. Structures are the product of but also a medium for social action; they are not only barriers but also generating moments of social action. When reproducing specific social practices, actors have to draw on existing rules which at the same time structure social practices.

Structures, according to Giddens, do not exist in reality they only exist as memory traces in human minds. People internalise the rules that are made manifest only in the instances 
when they are drawn on in social action and interaction (Walsham 1993: 61). Structures exist insofar as they are produced and reproduced in social practices. Therefore, we can also speak of 'virtual structures.'

Social rules and structures, on the other hand, enable people to act in a competent and context-adequate manner. In acting according to the rules human agents not only reproduce existing social practices but they also confirm their institutional character. However, there is always the option of 'doing otherwise'; every social actor controls some resources which give him the power to influence existing practices. Although the disposition of social actors is primed to act in a specific way, they always have the option to change social practices; they do not have to reproduce them schematically. Human agents always monitor their own conduct and its results in a reflexive manner and if they do not produce the expected results, they can either act differently, changing existing rules, or they have to adjust their goals and expectations. This reflexivity together with the concept of unintended consequences of purposeful action implies "that all action carries within it the seeds of change" (Walsham 1993: 61).

The basic concept of Giddens' structuration theory can be illustrated by the following figure 2:
Here, both social structure and social action and interaction are broken down into three dimensions and then interlinked by three modalities: Human communication always involves the use of interpretative schemes; they represent stocks of knowledge which help human agents to make sense of their own and others' action. At the same time, social actors produce meaning or, as Giddens terms them, structures of significance.

In processes of interaction, human agents also utilise power by drawing on facilities to allocate material and human resources and thus create, reproduce or change structures of domination. And human agents sanction their actions by drawing on norms or standards of morality and in so doing they maintain or modify social structures of legitimation. This breakdown of structures and interaction into three dimensions is done only for analytical reasons; in reality they are very much intertwined.

Giddens' general theory has a great disadvantage insofar as he does not pay a great deal of attention to the role of technology in the production and reproduction of social relationships (Wyatt 1998: 20). But when dealing with ICTs there is, of course, a need to specify the relationships between the 'technical' and the 'social'. Some representatives of 'social constructivism' deny any difference between the two, characterising technology as a seamless web (Bijker and Law 1992: 201).

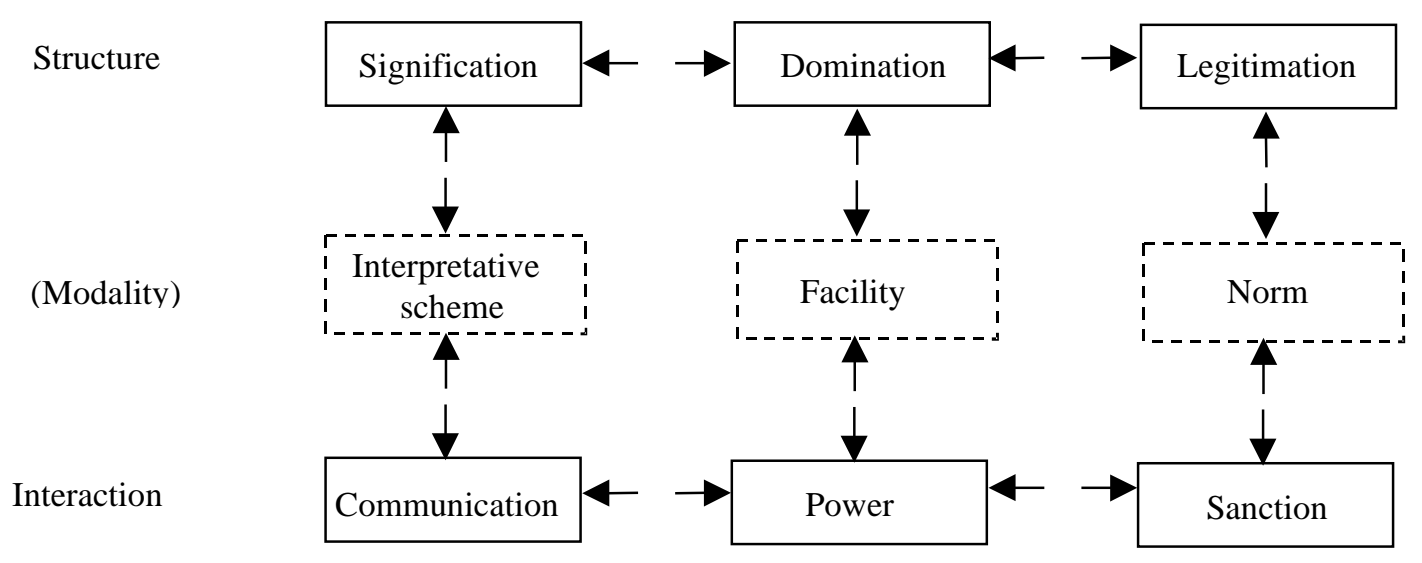

Figure 2: Source: Giddens, in: Walsham 1993, p. 61 
Against this perspective we can argue that modern ICTs are not mere social constructions that can be reduced to a set of social relations. While social relations are undoubtedly present, they do not comprehensively or essentially describe what those technologies are. ICTs possess an objective set of rules and resources that both enhances and constrains the roles of workers within organisations, they have an influence on the social fabric of the organisation (Sampler 1996: 10). To conceive of a social order as resting solely on interactions between human beings is to ignore the role that material resources play in shaping and substituting social relationships (Kavangh and Arujo 1997).

In technology research the concepts of 'technological practice' (Pacey 1983) and technology frames' (Bijker 1993) represent approaches that also claim to be helpful in transcending the duality of structure and process or the 'social shaping of the technology approach' and the impact analysis' of technology on society. Technological frames' include a variety of different aspects that influence interaction within and between individuals but also collective actors involved in innovation processes to improve technical artefacts. Bijker mentions goals, key problems, problem solving strategies, theories, tacit knowledge, testing procedures, design methods, users' practices, and the perceived substitution function of the new artefact as an element of a 'technological frame' (1995: 123-4).

According to Wyatt (1998), the notion of 'technological frames' has two advantages compared to the 'structuration approach': it takes the material nature of technologies more seriously and it has space for collective actors such as organisations. However, Wyatt continuous to argue, the 'technology frames approach' is too narrow, as it only analyses how relevant social groups involved in the process of innovation perceive users' practices. She therefore suggests extending the approach to the question of how people actually use technological artefacts and how artefacts are involved in the creation of social structures and relationships (Wyatt 1998: 23).

The concept of 'technological practices' is of particular interest as it draws attention not only to the relationships between the 'social' and the 'technical' but also includes a cultural dimension. Relying on Pacey's definition, technological practices are seen as having three dimensions: technological, organisational and cultural (1983). The three dimensions are very much intertwined: changes in one dimension also affect the two others, which means that all three dimensions have to be developed at the same time. According to Wagner (1994:15), ICTs intensify the explicit discussion of norms and rules; support the emergence of an integrated view of the organisation; create new levels of perception; and render interpretations and social practices more homogenous.

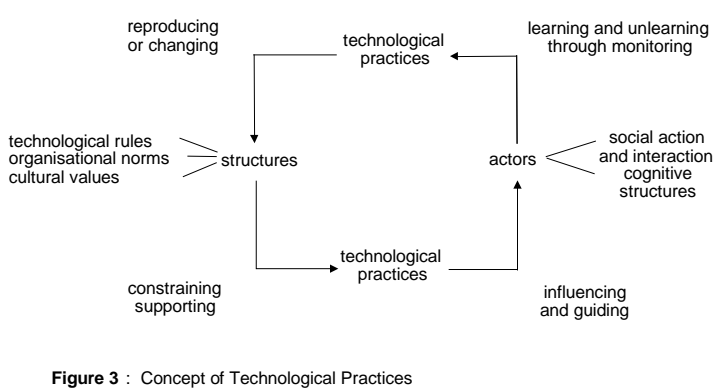

ICTs as multidimensional configurations are created by the interaction of groups and individuals but at the same time they also structure future interaction. As suggested by Giddens, we can separate the structural and action aspect of technological practices into three dimensions, as can be demonstrated by Management Information Systems. They provide interpretative schemes which managers can use to analyse and interpret data, take actions and make plans. Furthermore, they are facilities which managers of different levels and departments can use to co-ordinate and control other organisation members and they communicate a set of norms or values which indicate what is appropriate and what is not.

The concept of 'technological practice' also entails processes of 'learning by doing' and of 'incremental innovations', as it assumes that social actors continuously monitor the results of their activities and change their way of acting if the results do not match their anticipation. Continuous reproduction of new technological practices then leads to the institutionalisation of new technological, organisational and cultural structures. It is the concept of a 'feedback loop' that establishes a connection between techno- 
logical practices, on the one hand, and learning by doing and incremental innovation on the other.

Referring to a distinction made by Harris (1980: 65f), we can differentiate between primary and secondary technological practices. Primary practices develop within production processes, while secondary practices aim at integrating and co-ordinating primary practices; we can also talk of management practices, which can be distinguished from production practices (Schienstock 1993).

Production practices develop in single functional units or sub-processes, as, for example, in work groups. As such, technological practices develop more or less independently of each other. There is always the risk that frictions and conflicts will occur between different practice fields and that the whole production process will fall apart. This is why management practices have to develop; they have to ensure the smooth functioning of the total production process. Management practices can be characterised as interventions in the mechanisms of producing and reproducing production practices, aiming at guaranteeing a minimum of normative coherence, social cohesion and continuity over time. Management practices develop to make the various production processes compatible and to control the centrifugal tendencies in production processes. We must, however, take into account that the relationship between production and management practices is not one-sided; changes in the production process can also cause management practices to change and adapt.

The concept of technological practices causes major problems when it comes to research strategies. It is difficult to analyse the interaction of the technical, the social and the cultural dimension of technological practices as well as to reconcile structure and agency. To do research on technological practices it is useful to apply the concept of 'co-evolution'. Instead of looking at processes of reciprocal influence, one can analyse how technical, organisational and cultural structures, but also personal and collective characteristics of actors develop within time.

\subsection{Conclusion}

Above we have presented alternative functions of modern ICTs. Of course the different functions presented here often overlap to a great extent. Such functions can also be interpreted as dimensions of so-called 'Leitbilder' of applying ICTs. Here we will differentiate between two more general images of developing ICT-based systems: 'technological control of production' on the one hand and 'meaning-based coordination of actions' on the other hand (Boes 1996). In the case of the first 'Leitbild', the aim is to eliminate or at least to control human labour by transforming tacit knowledge into codified knowledge. This makes it possible to reduce alternatives of acting dramatically; the workers have to follow fixed and standardised sequences of acting, controlled by the pace of the technical system. ICTs as automation technology and as control devices are the two functions which fit very well with this 'Leitbild'.

In the case of the second 'Leitbild', control is not an aim for applying modern ICTs. Instead, the information system represents objects of reality and options for their processing. Work, in this case, can be characterised as interpreting the meaning of symbols. Tacit knowledge is seen as a valuable resource as it is crucially important for continuous innovation. ICTs, in this case, become media, which open up the opportunity for permanent communicative connectivity. They are not used to eliminate tacit knowledge by transforming it into codified knowledge, but to support its rapid and continuous exchange among workers. This allows for a collective interpretation of information and the development of joint ways of acting.

According to Sampler (1996), due to rapid changes, the characterisation of ICTs has shifted. In this respect, we can mention the price-performance improvements in semiconductor technologies, new types of technologies such as multimedia, the improved usability and power of software. "Together, these changes have shifted the fundamental emphasis away from computation towards communication and co-ordination of activities" (Sampler 1996: 19). This shift in the emphasis of ICTs also has an impact on the structuring of the work organisation. Together with the shift of emphasis of ICTs, a new organisation logic is 
developing. Before we analyse this new organisation logic in more detail, we will first discuss the changing nature of work related to the use of modern ICTs.

\section{The Changing Nature of Work ${ }^{3}$}

When we talk about the changing nature of work in the information society, two aspects are of particular importance here: the growing importance of information work and the increasing reflexivity of work. For the first aspect the fact that a new info-sphere is emerging alongside the techno-sphere is important (Toffler 1980: 165). Concerning reflexivity, both 'selfreflexivity' as well as 'structural reflexivity' have to be mentioned (Lash 1994).

\subsection{The Increased Importance of Information Work}

There is widespread agreement that the structure of labour is increasingly determined by activities like information acquisition, information processing, and information-based decision-making. The more efficiently the production processes can be regulated on the informational level, the more information work will gain in importance at the cost of work on the material-energetic level of the production process (Baukrowitz/Boes 1996). Information workers of various types whose work is confined to objects and 'material' which exist only on the level of information will replace those working on the material level.

'Interface workers', who influence the material level of the production process by way of the informational level and 'guarantee workers', who as 'guardians' and 'controllers' keep the production process running smoothly will become particularly important. Both groups concentrate their work - in contrast to information work in the strict sense - on the material level of the production process. This is the actual object and quality criterion of their work. But they manipulate their 'work object' indirectly, via the informational level or within the technical-mechanical system, and therefore they have to regulate and control their operations on the basis of the effects which the informational level produces on the material level.
The result of this process is that labour in 'information society' - due to the continued spread of ICTs based systems - is equipped with a new level of intervention, which inserts itself between human labour and the material and energetic level in production. Labour manipulates the material-energetic components in the process of production increasingly by means of this intermediate informational level, and changes its status within production as well as its own nature. It becomes - in essence information work, or information-mediated interface work.

In the course of this process of informatisation, the level of abstraction applied in handling the objects of the work rises continuously. Manipulation and perception become ever further removed from the material-energetic level of production - to be precise, in varying degrees, whether as information or as interface work. The connection between the informational and the material-energetic levels is becoming more fragile, due to the increasing 'universalisation' of the informational sphere.

A consequence of this 'abstractification' of work could be described as 'de-materialisation' or 'de-sensorisation'. In contrast to manufacturing operations, information work has still another characteristic feature: in manufacturing, the product has a material existence with material properties. Therefore the quality of such an object can be determined 'objectively'. In the case of information work, the quality of the product can be judged only within the context of a certain interpretation, which results from an - assumed - model of reality, itself a sociallyconstructed fact. The product of work in this case is a symbol in the network of social relationships, the object of analogous social interpretation, without being unequivocally determined.

The difference seems to be twofold: On the one hand, the objects with which information work is occupied are artificially created, they are artefacts whose existence is determined primarily by certain model assumptions about reality. On the other hand, the product of these operations is not objectively defined; the evaluation of its success is the result of a social process of interpretation. The work-process itself becomes part of a formalised information process which orients itself on the production 
targets. As a result - it is feared - working capacity will become negotiable and accessible to increasing control and to further phases of rationalisation.

\subsection{The Reflexivity of Work}

A further argument here is that under increasing systemic integration labour becomes selfreflective; in some way labour creates its own object of study. This development increases the importance of subjective participation in work operations on the part of the employees. Quality control and, within certain limits, the control of productivity as well, are shifted into workoperations. Therefore, in addition to the turnout of goods, labour has to check, improve and regulate itself to guarantee quality and efficiency. The borders between the process of routine work and that of innovation have become blurred: an increasing share of work consists of self-innovation. Furthermore, in systematically organised co-operation, labour must consistently and comprehensively monitor the behaviour of others, but also of itself, to be able to fit its own operations into the intended total operating performance of a work group and, if needed, to correct its own performance.

Lash also stresses the importance of 'selfreflexivity' but he also mentions 'structural reflexivity' as a new characteristic of work. Work, according to Lash, "entails self-reflexivity in that heteronomous monitoring of workers by rules is displaced by self-monitoring. It involves (and entails) 'structural reflexivity' in that the rules and resources (the latter including the means of production) of the shop floor, no longer controlling workers, become the object of reflection of agency. That is, agents can reformulate and use such rules and resources in a variety of combinations in order chronically to innovate" (1994: 119).

Schimank takes up the aspect of 'structural reflexivity' by stressing the increasing subjectivity of work (1986). Contradicting Braverman's traditional thesis, according to which the introduction of a technical system leads to an increase in control of the production process and to marginalisation of subjectivity, he argues that "subjectivity is just as necessary in the production facilities at present and in the future as it ever was in the past. - possibly even more so" (ibid.: 72). The reason for this basic need for subjectivity is formulated as follows: "The in principle insurmountable - inability of mechanised systems to insure the environmental conditions of its own operability is the source of the need for subjectivity in mechanised production facilities. Mechanical systems have to be linked with personnel systems. The vision of the fully automated factory is a technocratic illusion. Only subjectivity can re-integrate, when necessary, the horizons of reference which had been banned by techniques, to determine which environmental conditions were not anticipated by the assessment of mechanical operations and to convert them into conditions which can be mastered by the machinery." (ibid.: 82).

Wersig and Tacke add to this argument. While well-ordered relationships of co-operation are typical for Tayloristic work-contexts with correspondingly standardised communication, organised in the manner of an interface between employees, in systemically organised contexts, the relationships of the systemic integrated work to its surroundings and to other subsystems are, in principle, not capable of standardisation. Co-operation and communication are, therefore, neither sequential nor organisable as regular interface-relationships, but only reciprocal, with permanent and irregular communicative relationships (Wehrsig/Tacke 1992). They demand permanent self-reflection from the employees, which is only realisable by means of the subject-relationship on the part of the individual workers in regard to the conditions of their operations. The fundamental contingence of this situation in principle precludes acting strictly according to rules (ibid.).

\subsection{Work as a Problem-Solving Process}

Furthermore, customers no longer accept highly standardised mass products, instead they ask for more individual solutions. This process has been commonly understood in terms of 'diversified quality production' (Streeck 1989) in which increasingly specialised consumption entails more flexible ways of production (Piore and Sabel 1984). According to Kern and Schumann, the system regulator is becoming the key figure in manufacturing, who - instead of performing 
standardised tasks - is more engaged in 'problem-solving processes' (1984).

The same trend has been identified in the service sector, where the concept of a 'service out of one hand' also transforms work into 'problem-solving'. From this we can conclude that not only because of the integration of indirect and management work, but also because of the changing nature of the core process, direct production work has become more knowledge intensive. It is not only that the production of goods and services has become infused with symbols insofar as knowledge-intensive services have become central to many production processes, but at the same time the core production process itself has become more information-intensive.

\subsection{Routinised Work Will Survive}

It is important to mention that there are also some opposite trends, however. We should definitely not conflate the transmission of data between people with the acquisition of knowledge. Ernst and Lundvall distinguish between tacit knowledge, which cannot be codified or transmitted by ICTs, and information that can (1997: 35). When we differentiate between the notion of information and the need of knowledge, it becomes quite obvious that the concept of 'information society' and that of 'knowledge society' can have very different meanings. Processing and transmitting data are less demanding and less knowledge-based.

A number of recent studies on call-centres in particular casts serious doubt on the argument that there is a general trend towards knowledge-intensive work. On the contrary, they suggest that these new forms of work exhibit an extreme case of repetitive, tightly controlled, machine-paced, and less knowledgeintensive Taylorised work (Fernie and Metcalfe 1987, Reardon 1996; Incomes Data Services 1997; and McLoughlin 1997).

We also have to look at the concept of innovation more closely. Very often diversification and innovation are based on the standardisation of parts of the whole product. It is obvious that there is no general trend towards knowledge-based information work. Instead, we can expect some kind of polarisation with increasingly knowledge-based jobs on the one hand and more repetitive and less information and knowledge-intensive work on the other.

\section{Structural Changes in Work: The In- creasing Importance of Knowledge- intensive Business Services.}

Globalisation has contributed greatly to the stiffening of competition as national monopolies or oligopolies have collapsed. However, the fact that globalisation at the same time results in the establishment of new competition criteria is even more important. Today companies in all parts of the world, to be able to participate in global competition, must be capable of selling high quality products and services for a reasonable price and of delivering them within a short period of time. Price, quality and time can be seen as entrance barriers to the global market; success, however, depends upon the capability of companies to be first on the market with new products which meet their customers demands. Under the conditions of global competition, innovativeness and customisation are becoming the key criteria for economic success, particularly as the dynamic technological progress accelerates and as the life cycle of products shrinks across a broad spectrum of industries. This change in the dominant competition criteria has caused major structural changes in work.

In companies we can roughly differentiate among three processes: transforming inputs (material, energy, information) into outputs (products, services); securing the continuous execution of the transformation process; and coordinating and regulating the other two processes (Schienstock 1993: 9). The first type of process can be characterised as direct production work or core activities; manufacturing, for example, has the processing of material to produce goods as its core activity and for peoplecentred services the core activity can be described as care-taking or education. The second type of processes consists of indirect or peripheral activities, the function of which is to support direct production processes by providing resources (finance, knowledge) or marketing and distributing products and services. The third type of processes can be characterised as management work, entailing activities such as planning, organising, co-ordinating, and controlling. 
The information society, it is often argued, will be a service society. Structural changes in work are characterised by a growing share of services. However, a closer look at this trend reveals that in the emerging information society the so-called 'secondary services' in particular are gaining importance (Parmentier et al. 1993). These do not service the immediate demand of end users, but they are defined as those services which improve the production through increased support and use of human capital. They are important for guaranteeing the needed investment and organising and optimising business processes (Enquete Kommission 1998: 113). 'Secondary services' are generally characterised as 'knowledge-intensive business services'; they not only include indirect work processes but also management processes. The trend towards knowledge-intensive services contributes to the informatisation' of work.

When further analysing knowledge intensive business services we first have to take into account the fact that value added is mainly generated by product and process innovations. "Quicker innovation", as Lash argues, "entails that a lot more work must proportionally go into the designing of new products. It entails that a far greater proportion of the production process than heretofore must be accounted for by a knowledge-intensive 'design process', and a smaller proportion by the 'material process" (Lash 1994). But innovation also depends upon the research potential of the company. Although the results of basic research conducted in universities and state research institutes are publicly available, it takes constant investment effort in theoretical research for companies to be able to interpret and use abstract scientific knowledge (Cohendet and Llerena 1997). Companies can hardly make use of the public good 'new theoretical knowledge' if they do not conduct research themselves.

To a certain extent, we can see similar trends in the service sector. Often services are characterised as those activities in which output is essentially consumed when produced (Quinn 1986). Due to modern ICTs, however, for many services this direct relationship between production and consumption can be broken up. As Soete puts it: "Information and communication technologies, almost by definition, allow for the increased tradability of service activities, par- ticularly those which have been most constrained by the geographical or time proximity of production and consumption. By bringing in a space or time/storage dimension, information technology will make possible the separation of production from consumption of such activities, hence increasing the possibility of such activities" (1996: 48).

If services are tradable, their attraction for customers very much depends on their contents. It is the contents which will become the main value of service activities. Therefore, the design of such services becomes increasingly important. Moreover, when services are no longer immediately consumed, to do research to improve existing services or developing new services can become worthwhile.

The fact that an increasing amount of work is going into design and research processes is only one aspect of the changes in the structure of work caused by the globalisation process. As customisation becomes increasingly important, more work will also go into marketing. First of all, it is becoming important to know more about customers' needs to be able to provide products or services that can be sold. Furthermore, as customers no longer accept standardised solutions for their problems, instead of expecting specialised solutions for problems they are sometimes not even able to clearly define, it becomes necessary to develop new products or services in close co-operation with them. In addition, an increasing number of customers does not buy products or services only; they demand complex solutions, which often include long-term after-sales services.

The globalisation process also places high demands on management. Planning is becoming more difficult under conditions of increasing uncertainty. The same is true for the organisation function, since the design of production and service processes is becoming a process of learning and continuous improvement. We can conclude that more work will not only go into indirect work, but also into management work.

There is, we can conclude, an increasing demand for knowledge-intensive business services, including both indirect work and management work, while direct production or service work may decrease. In addition to what we have said so far, we also have to mention the increasing demand for further training. Con- 
tinuous incremental improvement as well as permanent organisational adaptation and renewal can only be realised if workers get the chance to improve their knowledge continuously through lifelong learning.

The transformation of work seems to indicate that more and more employees will be working in peripheral and management functions and fewer in core activities. However, this is obviously not the case: companies seem to follow a strategy of strengthening the role of direct work and empowering direct workers on the shop floor. This takes place through integrating both indirect work as well as management functions into core activities, while those parts of the direct work with codifiable knowledge become increasingly automated. A general trend can be identified towards reducing both the share of functional specialists performing peripheral work and the share of middle management, while at the same time the share of direct workers also performing indirect and management work will increase. This trend of the transformation of work can be observed in manufacturing as well as in services.

\section{The Restructuring of a Business Or- ganisation}

In the following, we will first discuss the relationship between information technology and organisation forms, as this technology is often seen as the dominant driver of change. Here we will take a different view arguing that modern ICTs open up 'occasions for change', but they do not determine organisation forms. Both ICTs and organisation forms are open to other drivers of change. And it is the globalisation of markets that becomes the main driving force behind the development of a new organisation logic which will evolve in information economy.

\subsection{The Relationship between Information Technology and Organisation}

The debate on the impact modern ICTs may have on organisation structures is some forty years old (Leavitt and Whisler 1958). Since that time this relationship has become more complex, partly because of the environment in which it is developing, which has become more like a turbulent field, partly because the nature of modern ICTs has changed rapidly and new functions of ICTs have developed. While ICTs have increasingly interpenetrated work processes and have therefore become more important as organisation strategies at the same time the toolbox of organisation devices has also broadened: new models such as self-contained work groups, cross functional design teams or supplier networks have been introduced.

Thus the relationship between ICTs and organisation forms is not a simple one; concerning this relationship no clear picture has so far developed. A variety of perspectives exists, which, according to Sampler (1996: 6), can be summarised around five principle positions:

"(1) IT leads to centralisation of organisational control;

(2) IT leads to decentralisation of organisational control;

(3) IT has no uniform impact on organisational control but instead this relationship is determined by other factors;

(4) organisations and IT interact in an unpredictable manner; and

(5) IT enables new organisation arrangements, such as networked or virtual organisations."

In the following we will briefly characterise these approaches, using the main arguments evinced by Sampler (see 1996:5-11).

The first two concepts can be characterised as variations of an approach referred to as technology determinism. It is assumed that ICTs strongly constrain the options for organising production processes. ICTs are seen as an independent variable which in turn effects organisation structures as the dependent variable. Researchers arguing that ICTs will lead to the centralisation of control and decision-making point to the fact that this technology allows an easy and accurate transfer of information to senior management.

The decentralisation variant of the deterministic approach is based on two arguments:

- as IT will take over routine decisionmaking, individuals will have more time to deal with more complex problems 
- through ICTs huge amounts of information can be made available not only to top management but also across the lower level of the organisation. Having more information at their disposal, workers can become involved in more complex decision-making processes.

What the two concepts have in common is that they actually talk about the potential of modern ICTs, which means that whether their potential for controlling on the one hand or decentralising control and decision-making on the other hand is used depends upon other factors. Contrary to the deterministic approach, however, modern ICTs can be seen as fairly open technologies concerning organisation forms. As Naschold puts it: "Information technologies due to their structure of a hardware and software component are depending on the development of a separate social model of production. The regulation of social relationships is an endogenous and functionally necessary part of the development of the technological system..." (1986: 232).

Another school of thought analyses the organisational requirements set by the environment in which the company operates. Organisational characteristics such as information processing needs determine whether and how ICTs will be used. Companies operating in a very uncertain environment, for example, have greater information processing needs than companies working in a stable environment. These different needs influence the way in which ICTs are applied, as they represent one strategy to fulfil the information requirement. An alternative strategy to reflect information needs is the choice of the organisation form, which can support but also inhibit and control information exchange. Besides environmental uncertainty, organisation size, task variety and knowledge about the task as well as the degree of task connectivity are also mentioned as contingent factors affecting ICT applications and organisational design.

Another approach argues that the use and consequences of the introduction of modern ICTs is unpredictable as they emerge from complex interaction processes. On the one hand, ICTs possess an objective set of rules and resources that changes the roles of workers and the social fabric of the company. The way in which ICTs are implemented and used, on the other hand, depends on the meaning attributed to them, which itself is socially constructed. To be able to make any prediction about the relationship between ICTs and organisation forms, knowledge is needed about the way ICTs are used and for what purpose; but also about the organisational processes evolving around the implementation and use of modern ICTs.

The last approach argues that technology and organisation are truly homologous forms; information technology creates new organisation forms and new organisation forms, in turn, provide new opportunities for technology design (Berger 1993). Neither technology nor organisation is fixed, but both are changing in relation to each other; therefore, the design of information technology and the design of organisation forms are largely becoming the same task (Lucas and Barondi 1994: 9). Communication technologies offer opportunities to manipulate according to specific aims both the communication technologies themselves as well as the organisation contexts in which they are embedded. They provide, as Fulk and deSantis argue, more than traditional technologies, 'occasions' for structuring the production process according to other drivers of change such as innovativeness, cost-saving, control, or quality (1995: 337).

This approach continues to argue that due to the fact that shifts in the environment and customer demand occur, companies have to fundamentally restructure their organisation more frequently. One particular argument is that the pressure for continuous innovation caused by global competition forces companies to adopt more flexible organisational arrangements. In this respect, one can talk of a new organisation logic. The development of this logic, although not caused by the broad diffusion of modern ICTs, is nevertheless supported by them.

The following picture shows the various perspectives of the relation between organisation structure and modern ICTs. 


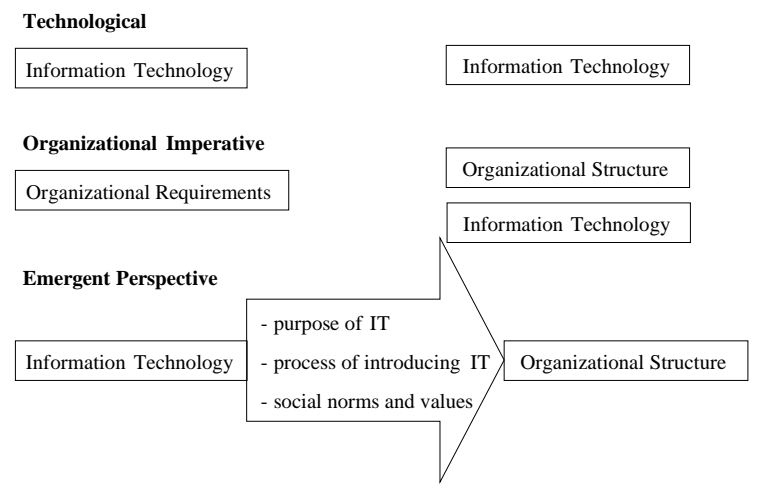

Figure 4: IT and organisational structure Source: Earl, M. (1996, p. 9)

\subsection{The New Organisation Logic ${ }^{4}$}

There is widespread agreement that the newly emerging information society will bring with it new ways of organising production. This is often called 'post-Fordism' (Amin 1993), characterised by 'flexible specialisation' (Murray 1987, 1988), just-in-time production' (Hay 1988; Ling and Goddard 1988) and a high degree of outsourcing (Cole 1981). Studies arguing in this way proclaim the end of both Taylorism and Fordism, but draw their examples almost exclusively from the car industry and the textiles and clothing sector (Zeitlin 1991).

On a more practical level, such ideas underpinned a series of prescriptive models for restructuring which were promoted to employers under such slogans as 'lean management' (Lamming 1993; Womack et al. 1990), 'downsizing' (Tomasko 1990), 'rightsizing' (Hendricks 1992) and business process reengineering' (Bartram 1992, Coulson-Thomas, 1994). The ideas promoted in this literature include reducing staff numbers, delayering management and, in some cases, disaggregating large organisations into smaller profit centres or cost centres. Later, this approach developed further into concerns about supply-chain management and knowledge management. These models, however, seldom discussed the role of modern ICTs in the transformation process.

In the following, we will not deal with single aspects of organisational restructuring but will try to develop an understanding of a new organisation logic which will emerge in information society. ICTs, as has been argued ear- lier, will have an important role to play in the development of new organisation forms, but they are not seen as a determining factor. They open up 'occasions' for organising production processes, but as to technology applications and organisation forms, both are open to other drivers of change, particularly to the pressures of customisation and innovation competition.

In the literature attempts to describe the new organisation logic mainly list a great number of items without really uncovering the logic which is behind the development of new organisation forms. In the following, we will try to characterise this new logic. But first we will describe the logic which the traditional Taylorist/Fordist organisation model is based on.

\subsubsection{The Logic of the Fordist Production Model}

The basic assumption of the traditional Fordist model is that there exists a more or less unlimited demand for highly standardised consumer goods. At the same time, due to national monopolies or oligopolies, companies were not confronted with competitors from abroad. Their own internationalisation strategies were mainly based on exports, they themselves hardly invested abroad. We can characterise the environmental situation as complacent, secure and simple. As it was possible to anticipate the market trends for a longer period of time, the production process could be organised in a highly standardised, fragmented and formalised way. To avoid internal turbulence, a bureaucratic control structure was established which became a hindrance to extensive information exchange.

The Fordist production model is based on two important principles: functional specialisation and hierarchical integration. Functional specialisation is seen as contributing to productivity as workers specialising in narrow tasks can develop specific skills which will help them to work more effectively. The logic of hierarchical integration is explained by transaction cost theory. The argument here is that hierarchical integration will reduce companies' control expenses.

The Fordist production model is linked with a specific form of information flow; it contains channels in which only a vertical flow 
of information is possible and through which the acting of hierarchically arranged units is controlled. Actually, this model includes builtin mechanisms to block information flows; due to its bureaucratic structure and far-reaching division of labour, the model produces too many interfaces both hierarchically and vertically, which become a hindrance to communication and information exchange. There is a risk that within the Fordist production model too much information gets lost, particularly as in the bureaucratic control system the broad middle management is mainly dealing with the routine filtering of information.

In a globalising economy, where innovation competition dominates and customers no longer accept standardised mass products or services, but ask for individual solutions, markets become unstable, insecure and complex. Companies have to develop organisational structures and channels of information flow that can cope with uncertainty. Production can no longer be organised according to Fordist principles; instead, more flexible organisation forms are needed which allow for extensive information and knowledge exchange to improve and speed up innovation processes. We can actually argue that the new organisation logic is turning the traditional Fordist production model upside down: vertical de-integration and functional or process integration which can also transcend companies' boundaries are becoming the key elements of a new organisation logic.

\subsubsection{Vertical De-integration and Process Inte- gration as Key Aspects of the New Or- ganisation Logic}

The strategy of vertical de-integration is mainly associated with downsizing and outsourcing. Big companies reduce their size and become leaner to get the same entrepreneurial dynamism, innovativeness and informalism as small companies often have, to be able to react as quickly and flexibly as those do. Downsizing often takes place together with outsourcing. Nowadays, as companies reflect about their core activities and concentrate on these, an increasing number of functions is becoming the subject of 'make or buy' decisions. If units cannot compete with offers from outside suppliers, they are at risk of being outsourced. All func- tions and processes that do not belong to the core of the business can be subcontracted to other companies specialising in these activities. But not only peripheral functions are outsorced, sometimes even functions that can be considered as core business processes, such as design, become legally independent through outsourcing.

This results in smaller organisations with a more simple structure, which are supplied more frequently in smaller batches and therefore become more dependent on other companies. However, formal organisational relationships do not automatically turn into market relationships; instead, many outsourced parts are still linked very closely with, and are economically controlled by, the core company, based on longterm exchange agreements. In the end, a company may develop that subcontracts all production and is only concerned with product design, marketing and the management of all activities in the chain conducted by other companies. Electronic networks make such partnerships possible, since they reduce the costs of coordination and transaction.

A criterion to distinguish between different types of networks is the degree to which one partner in the network influences others. In a traditional EDI application concerned with data exchange, partners have more chances to react to the other network actors, since they have faster access to more reliable information, but the different organisations continue to operate autonomously. Different levels can be distinguished until finally the reciprocal influence by the actors of the network is so intensive that the separate organisational context fades and the network itself emerges as the new organisation. Then one is not far away from the theoretical concept of the 'virtual organisation', which is no longer bound to time or distance.

The establishment of 'cost and profit centres' is another strategy to reduce vertical integration. More autonomy is given to the firm's divisions, while at the same time they become fully responsible for costs and profit. The tasks and responsibilities of the headquarters, on the other hand, are reduced quite significantly. According to Hedlund and Rolander, in so-called 'heterarchically' organised companies responsibility for product groups, functions and specific territories can be decentralised in such a 
way that many parts have a say in the company's decision-making process (1990). Loose coupling and direct negotiation among subunits, particularly concerning transfer prices, is typical for a 'profit centre organisation'.

The restructuring of service functions within companies is also part of the organisational renewal process. Again, the principle of process integration is applied. Finance, purchasing, personnel, accounting, long-term planning controlling and logistics are integrated in service or advice centres, which are to deliver the necessary services within the company and to external agencies, to take responsibility for corporate development, and to ensure the organisation's goals are attained. These centres are also responsible for costs, time and the quality of their services.

A consequence of the introduction of cost and profit centres is the flattening of hierarchies as organisation levels between headquarters and the centres become obsolete. But the reduction of organisational levels of bureaucracy continues further down the hierarchical ladder as companies become more aware of the disadvantages of such a large bureaucracy: slow information exchange and even loss of information, lengthy decision-making processes and particularly a non-innovative business culture. All these consequences of large bureaucracies will become serious problems in an economy where business success depends greatly on companies' innovativeness.

Internally, companies need to organise their production process around customeroriented processes rather than functions. The implementation of ICTs is aimed at eliminating steps in the hierarchy and create flat organisations, instead of centralised organisations where computer systems are established around mainframes. The most important aspect of an organisational strategy of process integration is the introduction of group work. Traditionally work is divided into many different tasks and workers are specialised and located in separate departments. In a process-oriented structure, teams perform activities which are traditionally spread all over the organisation. This implies that many unproductive activities such as control and waiting for decisions taken higher up the ladder are made redundant.
Work groups become responsible for selfcontained production processes without any fixed division of work among their members. If teams are assigned to perform a whole process, they also need to be given the responsibility for it. Work groups have to organise themselves; they are expected to continuously optimise the way in which they organise their work. But at the same time, by monitoring each other, work groups should also continuously improve their co-operation and information exchange. Learning by doing and by interacting are important aspects of group work.

Work situations will be described less by restrictive job descriptions. Each individual is no longer responsible only for his own task, but also for the end result. The barriers between different qualifications in small groups become blurred. Everyone becomes better acquainted with different steps of the production process. In this way the delimited responsibility which goes hand in hand with a specified job that fits nicely within the ladder of hierarchy will fade. Smaller teams of workers can process increasingly complex data flows in and between organisations. The new communication technology enables these small groups to get easy and fast access to the necessary information.

Such re-allocation of tasks affects the position of middle management. Their position was based on filtering and spreading the information coming from above in the organisation. If there are less hierarchical organisations where workers have to solve problems directly they themselves need to have the necessary information at their immediate disposal. The increased opportunity to directly control work processes through ICTs further erodes the position of middle management. Their responsibilities should be rather coaching and motivating the teams instead of controlling and directing them.

Similarly, within companies, ICTs allow for a faster transfer of data between departments. Through the implementation of ICTs, companies can get the work done faster in the organisation. The treatment of a file through many different steps done in several departments or locations can be accelerated. A material file no longer needs to be transported physically and some intermediate steps are rendered redundant. 
The group or team approach is also applied to organise the development and the design processes. A new style of innovation management reintegrates research and development with engineering, design, procurement, production and even marketing. The development of new products, quality control, market assessment and price calculation - all these activities are performed within a cross-functional team consisting of members from various departments. The idea of such teams is that all products are designed with manufacturing in mind but also to speed up marketing.

As has been said earlier, process integration can also take place across company boundaries. Large companies completely restructure their supplier chain by reducing the number of suppliers drastically. At the same time, a new division of tasks takes place; suppliers have to produce complete systems which can be assembled directly without any contribution from the core company. Furthermore, supplier firms have to take over additional tasks, particularly research and development; the innovation process becomes more like a joint undertaking of networked firms. In addition, customer firms can take part in the coconstruction of new products, to avoid marketing problems.

In view of these assertions, it is all the more surprising that empirical research (Huys et al. 1995) on organisational restructuring sometimes tells a different story. Several sector-wide studies (chemical, automobile, machine tool and clothing industry) have investigated the transformation from a traditional Tayloristic division of labour to a new socio-technical division of labour. Although in some respects changes in the organisational structure do take place, the effects on the work content of production workers remain limited, with a continuing domination of merely implementational and small jobs. The researchers attribute this slow transformation to the larger than expected adaptability of the Tayloristic production concept to meet the demands of the changing environment and to the rigidity of the employment relationship which influences the dominant production concept. This would suggest that at least in these traditional industrial sectors the potential of ICTs is not fully exploited. The (few) empirical results available do not support the recommendations of the OECD (1995) that "the diffusion of ICTs should be accompanied by a restructuration of production and work organisation".

\subsection{Changes at the Boundary of the Firm - Spatial Flexibility ${ }^{5}$}

Another aspect of the reorganisation of work, the spatial relocation of activities, which is made possible by the use of ICTs, is taken up in the literature under the heading of teleworking. In the following we will discuss briefly the main forms of ICT-supported spatial relocation of information-processing work.

The first of these concerns home-based working, which falls into three broad types: work which is partially based at home and partially in the workplace (generally carried out by employees in medium or high-skilled technical, professional or managerial occupations); fully home-based work for a single employer (generally carried out by low-skilled workers, often paid by results and without secure employment contracts) and freelance homeworking.

There is considerable evidence that teleworking works best where hierarchies are flat, bureaucratic rules are minimised, job descriptions are flexible and workers are encouraged to work towards targets which they have negotiated with their managers or team-mates. This form of teleworking tends to prosper best with a managerial style which is nurturing and enabling, rather than autocratic or dictatorial - a 'maternal' rather than a 'paternal' model - in which trust plays a crucial role. There is also evidence that flexible teleworking is easier to introduce into organisations which already have a well-developed electronic communications culture - in which the staff is already used to using voice-mail, e-mail and other forms of communication which make location irrelevant and which facilitate asynchronicity (in other words, which make it easier to shift messages in time as well as space). The introduction of intranets is currently spreading such communications culture rapidly. Having an intranet makes it immediately visible who is just sitting on information and who is doing something productive. And it encourages people to go straight to the source for the information they need, instead of going via line managers. It 
seems likely that the spread of intranets may also contribute to a reduction in numbers of middle managers.

The second form of home-based teleworking - fully home-based working - has more often been included in studies of 'traditional' forms of homeworking (Phizacklea and Wolkowitz 1995, Huws 1994). Researchers have tended to find social isolation, precariousness and ignorance of legal and social security rights amongst this group. However, a simple 'exploitation' model does not fit the evidence comfortably. Many of these workers express considerable ambivalence about their position. If they were not working from home they would probably not be working at all and they tend to view it as a freely chosen option which represents the lesser of two evils. The interaction between structure and agency is complex and multi-faced here.

Freelance teleworkers usually have lower earnings than would prevail in equivalent office-based work, and suffer from extreme unevenness in the flow of work, with periods with too much alternating with those when there is none at all. The latter cannot be enjoyed as leisure because of the fear that new work might never arrive. Huws et al. found a paradoxical situation whereby most freelance teleworkers claimed to have actively chosen this way of working because it offered autonomy, control and the freedom to 'be your own boss'. Yet in reality, because of the unpredictability of their situation and their relatively low earnings, they had less control over the disposition of their own time than equivalent office-based workers. They were, for instance, unable to plan holidays because they never knew whether an urgent job might appear on that date (Huws et al. 1996).

A second category of teleworking is mobile or nomadic working. Although there is some evidence that a large and growing number of workers falls into this category, it has been insufficiently researched. There is, however, some evidence that the typical mobile worker (compared with a home-based teleworker) was likely to be younger, and more likely to be a man, and working exceptionally long hours (Huws 1990).

A third category of teleworking involves organising workers into 'virtual teams' or 'virtual organisations' regardless of location. These consist of individuals working out of physically dispersed workspaces, or even individuals working from mobile devices and not tied to any particular workspace. They often form temporary small groups to solve specific problems. As soon as a solution to the problem has been found, the group dissolves and its members start to work in another group, often with different partners. In general, people work in several groups at the same time. Through this we can see the development of a network of overlapping group structures.

The lifeline to the network and major source of integration is the communication link among collaborative workers. No established organisational structures exist; instead, job responsibility and lines of authority shift regularly in virtual organisations. These new forms can therefore be characterised as 'co-ordination intensive structures'. Many patterns and relationships between the members of the virtual organisation exist, but to function this organisation form needs extensive information and knowledge exchange via electronic network technologies. If vertical de-integration and outsourcing continue we may see new network forms evolving, consisting of a multitude of very small organisations and single persons.

Finally, we come to the relocation of whole functions to back offices or call centres, either in-house or outsourced. These generally involve a relocation of work to other regions or, indeed, another country.

\subsection{Conclusion}

Based on what has been said so far, we can characterise the new organisation logic as mainly relying on the governance mechanism of networking, which integrates both the flexibility advantage of the market and the stability advantage of bureaucracy. Three levels of network structures can be identified:

- an intra-organisational network structure which develops between sub-units, replacing the bureaucratic governance regime; this increasingly includes global production networks as companies break down their value chain and locate discrete functions in different regions all over the world; 
- an inter-organisational network structure which develops between companies, replacing the market as the traditional mode of co-ordinating exchange;

- a network of teleworkers associated with companies in different ways.

\section{Social Exclusion ${ }^{6}$}

Social exclusion has become the key concept in the international debate on social disadvantages. This signals the increasing awareness of social risks related to the current socio-economic transformation process. At the end of this century, as Touraine argues, the point is no longer a matter of being "up or down", but of being "in or out" (1991: 8). In France the concept of social exclusion, based on the tradition of social solidarity, became popular already in the 1960's and has played a vital role in shaping the theoretical discussion, the political discourse and state intervention since then. However, the discourse on social exclusion did not spread across Europe as a whole earlier than the late 1980s or beginning of the1990s (Silver 1994: 535).

In 1989, the Council of Ministers of Social Affairs of the then European Community passed a resolution to combat "social exclusion and to support integration and a Europe of Solidarity". The Observatory on National Policies to Combat Social Exclusion was established in 1990 by the European Commission. And the White Paper "Growth, competitiveness, employment" published by the European Commission in 1994 called for a fight against exclusion and "the poverty, which so degrades men and women and splits society in two". During the 1990s, several European countries, among them Germany, Italy, Portugal and Denmark, have taken action on social exclusion and have also established new institutions. Recently the British government published a report on social exclusion in that country and has proposed concrete measures to fight social exclusion (Social Exclusion Unit 1998).

While in France the debate about social disadvantages has always focused on a wider perspective of people's active integration into the social dialogue with its policy emphasis on social solidarity, in the British tradition the dominant concept to study of social difference has been that of 'poverty'. This has given rise to the notion of the 'poverty line', an arbitrarily defined and relative income threshold below which people are defined as 'poor' and a policy focus on measures to relieve 'poverty traps' (Parker, 1995) or provide income support (Evans, Paugam and Prélis 1995).

A different, but related concept, much used in Britain but also in other European countries, is that of 'inequality' (which also tends to be used in an empirical and descriptive sense, rather than a theoretical and dynamic one). This concept is used in relation to a number of different variables, including gender, race, disability and age, which affect an individual's chances of entering employment, obtaining access to skills and earning power. Research on social inequality aims at identifying the disadvantages of specific social groups in comparison to others. Obtaining access to skills, for example, is in general easier for men than for women.

\subsection{The Concept of Social Exclusion}

The list of attempts to define social exclusion is endless. All observers of this phenomenon agree that it is difficult to give an exact definition. The concept is very vague and ambiguous, as it includes various economic, social and political aspects. During the last years ever more types of social disadvantages have been subsumed under the concept of social exclusion and ever more social groups have been characterised as excluded. Due to this ambiguity, it becomes very difficult to delimitate it from other concepts of social disadvantages. Somehow one can argue that the concept can be made to express virtually anything.

The concept is rooted in the concept of 'social dialogue', which in its turn can be traced back to the notion of society as a body in which all individuals should be included as active participants. Therefore, social exclusion is defined as "breaking of the social ties" (Xiberras 1993). This definition assumes some kind of a clear line dividing "inside" and "outside", it understands social exclusion as a monolythic phenomenon. Crossing the borderline would mean that individuals have become excluded. No gradual scale of membership in a social system seems to be possible, but only abrupt, definitive exclusion. To avoid such a strong 
demarcation the pair of opposing terms: exclusion/inclusion or exclusion/integration has been introduced (Luhmann 1994). The fact that various degrees of integration can be identified makes it possible to speak of exclusion/inclusion as a relative concept (Xiberras 1993: 25).

As there are many ties that link people with society, social exclusion is seen as a multidimensional and cumulative phenomenon (Stichweh 1997). Normal life takes place in various social spheres: work, education, health care, leisure activities, housing, and cultural life, for example. Not participating in one of these spheres cannot be seen as exclusion. For example, lack of employment does not in itself necessarily lead to exclusion, but only in the interaction or in a sequence of collapses of various inclusions. Only those people that do not participate in all or at least the majority of the various social spheres can be characterised as excluded.

The processual character of social exclusion is also very often stressed. Paugam (1993) defines exclusion as a process of 'social disqualification' that occurs in three consecutive stages: fragility (under/unemployed but retaining links with society), dependence on social aid (discouraged from work but filling other social roles), and then complete breakdown of social bonds. Castels (1992) also characterises exclusion as a dynamic three-stage process running from full integration through precarious, vulnerable employment and fragile relations to disaffiliation or exclusion. The zone of vulnerability is strategically important as it "designates the crumbling of the social tie before it breaks" (Castels 1992: 138). Exclusion is then perceived as the accumulation of various disadvantages, as the last stage in a process of social disqualification (Paugam 1993).

On the basis of what has been said so far, the notion of social exclusion implies a relative and process-linked vision of degradation with respect to a certain status experienced previously, at the end of which the person finds himherself cut off from all circles of social exchange. Therefore, in general, the state of social exclusion pinpoints a situation that manifests a certain deterioration with respect to a previous situation. Integrated subjects can become vulnerable because of organisational transforma- tion in the working environment and these vulnerable people can fall over the precipice into social exclusion. The excluded would then occupy the fringes of social life, characterised by the loss of employment and, then, social isolation. In this way, it is possible to analyse the distinctive reasons and intermediary stages of the process of professional de-qualification in their identified stages within specific and differentiated courses. From this point of view notions such as loss (of role, autonomy, tasks), marginalisation, precariousness or vulnerability seem to be decisively more appropriate to describe phenomena of risk ultimately leading to exclusion that can strike workers whose working environment has been qualified by technological innovations and organisational restructuring processes.

In the following we will further clarify the concept of social exclusion by confronting it with the concept of social inequality. The two approaches differ in the following aspects:

\begin{tabular}{|l|l|l|}
\hline & \multicolumn{1}{|c|}{$\begin{array}{c}\text { social } \\
\text { exclusion }\end{array}$} & \multicolumn{1}{|c|}{$\begin{array}{c}\text { social } \\
\text { inequality }\end{array}$} \\
\hline $\begin{array}{l}\text { areas of so- } \\
\text { ciety covered } \\
\text { by the con- } \\
\text { cept }\end{array}$ & $\begin{array}{l}\text { different } \\
\text { areas of } \\
\text { society }\end{array}$ & $\begin{array}{l}\text { focus on the } \\
\text { economic } \\
\text { sphere }\end{array}$ \\
\hline dimensions & $\begin{array}{l}\text { multidimen- } \\
\text { sional }\end{array}$ & $\begin{array}{l}\text { one dimen } \\
\text { sion }\end{array}$ \\
\hline $\begin{array}{l}\text { perspective of } \\
\text { the concept }\end{array}$ & $\begin{array}{l}\text { dynamic } \\
\text { concept }\end{array}$ & static concept \\
\hline $\begin{array}{l}\text { character of } \\
\text { the concept }\end{array}$ & $\begin{array}{l}\text { including } \\
\text { subjective } \\
\text { aspects: } \\
\text { vulnerability }\end{array}$ & $\begin{array}{l}\text { objective } \\
\text { concept: } \\
\text { distribution } \\
\text { of economic } \\
\text { resoures }\end{array}$ \\
\hline $\begin{array}{l}\text { political } \\
\text { aspect }\end{array}$ & $\begin{array}{l}\text { participation } \\
\text { in the social } \\
\text { dialogue, } \\
\text { empowerment }\end{array}$ & add resources \\
\hline
\end{tabular}

Table 3: The concepts of social exclusion and social inequality compared

While many authors recognise the complexity of the phenomenon of exclusion, we will use a more limited concept, focusing on work (see also Nasse 1992). Employment is seen as the core of the social tie as our modern societies have privileged economic exchange and thus remunerated work (Foucauld 1992: 6). Now the 
globalisation of markets threatens social cohesion and social transaction.

\subsection{Organisational Restructuring and Social Exclusion}

One major consequence of the introduction of the new organisation logic, as we have described it earlier is the destabilisation of bureaucratic career structures enjoyed by a large proportion of managerial and professional staff. Fewer of those in such occupations can now be guaranteed lifelong employment and continuous career advancement (Brown 1995). This does not mean that the restructuring strategies of companies will lead to an absolute decline in the number of jobs in management and specialist functions, on the contrary, projections of the future demand for managerial and professional workers suggest a significant increase. Furthermore, knowledge-intensive business services is one of the few sectors with continuous job growth.

Although there seems to be a growing demand for managerial, professional and knowledge workers, at the same time we can identify an increase in the sense of 'risk' among employees in these occupations. With the demise of the bureaucratic business structure these groups of workers have to accept flexible careers (Brown and Scase 1994). An inevitable feature of 'flexible career' patterns, according to Brown, is that they are inherently insecure (Brown 1995: 36).

A consequence of this development is that unemployment is constantly affecting new categories of people. Those workers who had been employed for a long time in 'normal', that is to say non-precarious, conditions are now being made redundant (Yépez del Castillo 1994: 619-620). Of course, low-skilled workers are more threatened with becoming unemployed than qualified workers, but lay-off caused by outsourcing, streamlining and restructuring often affects middle management and specialists in particular. The outsourcing of the R\&D department or its transfer to other countries is one example. In this case not individual, less qualified people are selected to become redundant, but whole work groups and departments are closed down.
Restructuring strategies caused by global competition have contributed significantly to the massive increase in unemployment. What is striking, however, is not the scale of unemployment but its structuration. It is the increasing long lasting nature of the phenomenon that causes severe problems, since more and more workers become long-term unemployed. Salais mentions the proliferation of unstable forms of employment is an important factor that causes long-term unemployment (1980). In a situation of decreasing labour demand it becomes more and more difficult for the unemployed to find a normal, non-precarious employment. Instead, the newly unemployed are constantly moving from one insecure and unskilled job to another, while young and highly qualified people are the beneficiaries of newly created, more demanding jobs. But even the majority of the newly created jobs are based on precarious work contracts.

For those who are unemployed the risk of becoming long-term unemployed and finally totally excluded from the labour market increases exponentially with the length of unemployment. "This dual trend - precarious employment and recruitment of over-qualified workers - continuously pushes to the back of the queue those among the unemployed who are considered to be the least productive (Yépez del Castillo 1994: 620). Women, unskilled workers and persons over the age of 50 are those groups which are mostly at risk of becoming stigmatised.

Often our future society is described as being highly segmented. We can expect, it is argued, that only a small group of core workers will have a secure work status and contracts of indefinite duration. Core workers are those, whose skills are most essential to the main activities of the firm. They are required to accept 'functional flexibility' (Beatson 1995), also known as 'internal flexibility' or 'flexibility on the intensive margin' (Hart 1987) that concerns the employer's ability to vary the allocation of work within the organisation so that changes in their jobs can easily be made when required. Functional flexibility may be accomplished by the introduction of ICTs but this coincidence does not necessarily imply a causal relationship. However, it is clear that a major technological change can provide a pretext for introducing functional flexibility and all the social innova- 
tions included, such as multi-skilling or group work. The technology also provides a means of monitoring and managing complex and variable work patterns.

There is, however, a second form of flexibility, often known as 'external flexibility' or 'flexibility on the extensive margin', (Hart 1987). This takes the form of varying the size of the workforce in response to changing requirements, whether these involve seasonal fluctuations or responses to changes in customer demand or market changes. These forms of flexibility may involve the introduction of temporary working, part-time working, homeworking, on-call working or casual labour (Atkinson 1995). Workers in this segment can be called peripheral workers, they conduct those activities which are less critical to the firm's core activities.

Many of these forms of flexible working involve the employment of women (Huws et al. 1989). Because these forms involve the rapid movement in and out of the workforce (and hence, very often, the benefit system) and a blurring of the boundaries between work and non-work, it is this type of flexibility which appears to have the greatest potential impact on social exclusion. Part-time, temporary, on-call or other flexible workers may well find themselves outside the remit of social protection regulations, precarious, poorly paid and socially marginalised (Huws 1998). Here too, ICTs have played a crucial enabling role, if not a determining one. Typical large supermarkets, for instance, will have up to 200 different shift patterns in operation in any given store in any given week (Huws, Hurstfield and Holtmaat 1989). Without a computerised system it would be impossible to manage such a complex system either from the point of view of responding to fluctuation in consumer demand or from the point of view of calculating the payroll.

The third group comprises external workers distanced from the enterprise; generally they are service suppliers, subcontractors or selfemployed workers. They do not have conventional career perspectives and employment security. It is likely that their status of employment will change very often. People may be employed on the basis of a short-term conventional labour contract, they may work as independent entrepreneurs on a contract, or they may become unemployed for some time. Their work situation will become much more insecure.

Our traditional understanding of core and peripheral workers, however, does not seem to hold true any longer. We can see new risk groups arising, such as middle management, foremen or some specialist groups, which were for a long time seen as core workers, sheltered by 'internal labour markets'. Obviously for some groups of employees, formerly perceived as core workers, these internal labour markets are about to disappear.

On the other hand, we can no longer equate peripheral workers (without long-term contracts) with those who have a weak labour market position. Among the peripheral workers we can identify at least two groups: highly qualified self-employed specialists who work on a contract basis for companies on the one hand and low-skilled workers performing routine jobs (data collecting and processing) with very flexible work contracts (part-time, etc.). The first group actually has a very strong labour market position, as they can be seen as 'networked people', who due to their many connections can easily mobilise all the knowledge needed to solve complex problems.

No doubt self-employment has some advantages such as independence and taking more responsibility. But not all people concerned have chosen 'self-employment' voluntarily; often they are forced to accept this new employment form as the result of the outsourcing strategies of companies. They can be called 'fictitiously self-employed'. Although they have the status of independent employees, economically they are not independent, instead 'de facto' they work as employees dependent on their principle. The fact that an increasing number of normally employed workers is replaced by fictitious self-employed people may become a major problem as the latter are not covered by the protection mechanisms of the labour and social law (Enquete Kommission 1998: 130). Nowadays an increasing number of school leavers also start their working-life as enforcedly self-employed by the unemployment situation. 


\subsection{Regional Exclusion}

It is argued that the globalisation of markets will lead to economic convergence, as it allows each region to specialise and to develop specific advantages that will attract big trans-national companies to invest and set up businesses. This argument, however, ignores the fact that regional specialisation is always tied to the demands of companies. Companies' strategies to organise their production processes on a global scale, however, do not only create chances for a high road development'; low road development' perspectives are also produced (Sengenberger and Pyke 1992), since for some of their products or parts cheap labour and less restrictive environmental regulations are seen as advantages particular regions can offer.

Because of the fact that companies, when organising their production processes globally, are looking for both a 'high road' and a low road' environment, only a limited number of regions can acquire the position of a knowledge and decision centre in global organisation networks (Amin 1993). Many regions, however, although they are integrated into global production networks, are caught in the trap of a low road development'; less value creation seems to be their fate. Often a less qualified workforce, traditional value patterns, ineffective institutions and traditional regulation practices reinforce this development, which makes the changeover from a low road to a high road very unlikely. Instead, the less developed regions compete against each other; economic development becomes a 'zero-sum game', one region loses what the other gains. In their attempt to catch up with the high road regions, less developed regions start to put each other in the shade through low wages, permissive environmental regulations and open-handed subsidies (Schienstock 1997b: 83). This means that social exclusion is no longer a phenomenon associated with individual courses of life only, but it is a collective fate.

\subsection{New Forms of Segmentation in the In- formation Society}

It is often argued that the transformation of the traditional industrial economy into what is called information or knowledge society will lead to new forms of social exclusion. Two trends are mentioned to underline this argument. One aspect is that the changing organisation forms of business processes and the emerging network structure in economy will result in prioritisation of certain types of occupations. Robins and Webster mention the following groups: "those which manage and operate across global networks, those which are capable of offering design intensity, those which can provide high added value to products and services through scientific excellence, imaginative skill, financial acumen, or even effective advertising" (1997: 9). All these jobs can be characterised as informational; they are increasingly interpenetrated by information work (Castells 1997).

Individuals are working out of physically dispersed workspaces, or even from mobile devices not tied to any particular workspace. In general they work on a short term and consultancy basis, drawing on their extensive networks and renewed knowledge to ensure effectiveness (Robins and Webster 1997: 9). As soon as a solution to the problem has been found, the group dissolves and its members start to work in another group, often with different partners. Their greatest quality therefore is a high level of flexibility. These people are called information or knowledge workers or symbolic analysts. It is assumed that they will make up about $30 \%$ of the whole work force.

At the same time, we can see a continuous transformation of tacit knowledge into codified knowledge. On the one hand, those people whose knowledge can be codified can be characterised as de-skilled, as their knowledge is no longer an asset which is needed in the production process. Soete speaks of an inherent skill bias of new ICTs, as an increasing number of skills are becoming totally codifiable and their importance is dramatically reduced (1996: 53). Those people with outdated skills and competencies will have difficulties to stay in work.

The growth of a group of highly skilled and very flexible knowledge workers on the one hand, and the increasing codification of knowledge on the other hand may lead to a process of segmentation in society. Authors like Reich (1992) or Castells (1997) assume that the symbolic analysts will not only rise in the upper ranks in companies but they will also take over 
key positions in society from property owners. However, the authors also fear that the great majority of workers, less qualified and flexible as they are, will form a new underclass which will be more or less irrelevant for informational society or capitalism. The information age, according to these authors, will be one which excludes a great majority of people, not only in less developed parts of the world but also in the metropolitan societies.

Lash (1994) also stresses the risk of social segmentation in future society. He speaks of 'reflexivity winners' and 'reflexivity losers', pointing to the fact that reflexivity is underpinned by an articulated web of global and local networks of information and communication structures. While in industrial capitalism life chances' and class inequality depend on an agent's place in and access to the mode of production, "in reflexive modernisation", according to Lash, "life chances - the outcome of who are to be the reflexivity winners and who the reflexivity losers - depends instead on the place in the mode of information. Life chances in reflexive modernity are a question of access not to productive capital or production structures but instead of access to and place in the new information and communication structures" (Lash 1994: 121).

\subsection{Policy Implications}

To prevent or combat social exclusion different approaches have been developed. They are based, as Foucauld (1992) argues, on a concept of social justice different from the one underlying the postwar social consensus which simply insured the population against predictable risks. We can distinguish between individualistic and collectivistic approaches. Individualistic approaches often define social exclusion in connection with citizenship and social rights. The Observatory on National Policies to Combat Social Exclusion, for example, states that social exclusion "can be analysed in terms of the denial - or non-realization - of social rights" (Room et al. 1992: 13-15).

The right to work can be seen as a key social right. The emphasis here lies on employment, not on income compensation through social welfare; the integration into the work process is the aim of strategies to combat social exclusion. Therefore, unemployed and school leavers having difficulties to find a job are the main target groups. The following measures of an active labour market policy can be seen as key strategy elements:

- the readjustment of the unemployed to new labour market demands

- the appropriation of wage subsidies for the creation of new jobs in firms

- the promotion of employment outside the labour market.

Training to readjust the unemployed to new labour market demands cannot be reduced to instructing workers in specialised knowledge only. Instead it becomes more important to strengthen their labour market position, as in future an increasing number of workers has to cope with the perspective of flexible careers. Therefore a variety of different skills and competencies such as social skills, learning how to learn, digital skills and management competencies are becoming increasingly important.

There is always the risk that wage subsidies will not create new jobs or at least no stable employment. On the one hand, it is argued that companies will only employ those workers who they need anyway; on the other hand, it is very likely that companies will only hire temporary workers. It is therefore important to combine employment based on wage subsidies with a qualification element. The promotion of employment outside the labour market dissociated work from employment; this means that people become socially integrated, although they are not occupationally integrated. Furthermore, such a strategy helps people to manage nonemployment (Yépes del Castillo 1994: 621). The promotion of employment outside the labour market is often combined with the strategy to guarantee employment for those people who have been unemployed for a longer period of time.

It is often stressed that to combat social exclusion one has to start before people become unemployed as unemployment stigmatises them and then it is more difficult to get a job. The realisation of the concept of lifelong learning may be helpful to avoid precarious employment and may even support people in starting a new career in a more promising work environment. For workers in precarious employment so- 
called adaptive qualification can be seen as a possible measure to avoid unemployment. In the case of skill miss-match employees have to acquire new skills through further training inside or outside the company. This strategy can also become a part of companies' human resources management.

For some risk groups continuous learning becomes a hard burden. Elderly people particularly often have difficulties in acquiring the knowledge needed to participate in learning organisations; their position in the labour market may be gradually weakened and in the end they may become excluded from the labour market (Ernst and Lundvall 1997: 15). It is possible to protect such people from being fired and becoming unemployed through collective agreements or legal regulations. The problem here is that protective regulations for specific groups increase the risk of other groups of becoming unemployed. "Social protection schemes have - in part at least - had a negative impact on employment in that they have, in the main, tended to protect people already in work, making their situation more secure and consolidating certain advantages. They have in effect proved to be an obstacle to the recruitment of job-seekers or of new entrance to the labour market" (European Commission 1993: 124).

The following presents a five-stage model of social exclusion and strategies for prevention are mentioned. The process runs from full integration (stable employment), through forms of precarious, intermittent or seasonal employment to unemployment and long-term unemployment and results in the total exclusion from the labour market, when people become unemployable.

Active labour market policy, including measures such as further training, wage subsidies or the creation of employment outside the labour market, may help individuals to avoid social exclusion, but one may have some doubts that this will solve the problem entirely. On the contrary, these measures are often seen as very limited, particularly in a longer perspective. To tackle the problem of social exclusion fundamentally a new solidaristic approach, or as Lundvall and Borrás argue, a new new deal is needed. This is not meant in the sense of guaranteeing material security but of re-establishing boundaries between excluded people and society.

Stage 1: Stable and long-term employment Intervention options: continued further training

Stage 2: Precarious, fragile employment

Intervention options: protection agreements, training to overcome mismatch between skills needed and existing qualifications

Stage 3: Unemployment

Intervention options: Wage subsidies, adjustment training

Stage 4: Long-term unemployment

Intervention options: Job guarantees, promotion of employment outside the labour market, further training and wage subsidies for firms to create new jobs,

Stage 5: Final exclusion from the labour market Intervention options: Training to keep workers employable, social aid

Table 4: The process of social exclusion and options for political intervention

The sharing of work is seen as the key approach towards re-establishing solidarity. The general reduction of working time is discussed as one option to employ more people. Dividing the existing working time among more people by reducing the general working time is, however, seen as a defensive strategy; a low demand is taken as given. Whether a general reduction of working time will have a significant impact on employment is still controversial, it is more seen as an instrument to stabilise than to increase employment.

Promoting part-time work is also discussed as a strategy for sharing work among a larger number of people. As part-time work is applied to low-skilled jobs in particular, it may help to reduce the problem caused by the rising need for skills and the increasing skill bias. The establishment of more flexible transitions from employment to other social spheres such as education, leisure, family, community and retirement is also seen as a promising approach to divide existing jobs among more people. The idea of such an approach is that if people have a real choice between different activities, without risking loosing their jobs, the supply of labour will be reduced and more people can be employed. 
Valenduc (1998) advocates a new balance between flexibility and security. The development of flexible forms of labour requires reflection on their implication on social security. Companies should be able to acquire more flexibility, while offering their workers an appropriate security. Workers may also wish for a more flexible form of labour, without abandoning a part of their social rights. Work legislation and the organisation of social security is too much based on the typical model of labour (one single employment, for one employer, in one place, full-time salaried and for an undetermined time). To combine security and flexibility, a more balanced agreement should be found in industrial relations between collective and individual arrangements. Collective agreements are needed defining a framework in which individual arrangements of working times are possible. Indeed, in addition to the flexibility demanded by employers, workers themselves should put forward their own flexibility requirements as:

- measures to combine family and professional life more easily such as parental leave, career interruptions, compatible working hours with the educational rhythm of children;

- measures that allow for lifelong learning and the development of competencies such as systems of replacement of workers in training, sabbatical leaves, credit hours and training holidays;

- measures to annualise working times, so as to compensate for peak-loads with longer holidays adapted to personnel wishes;

- new modalities to divide jobs, such as 'job sharing', free time in compensation for overtime work, additional jobs for night and weekend work, reduction in working time to prevent dismissals.

To reduce working time is generally identified as a defensive strategy to deal with the problem of social exclusion, as a low demand for labour is taken as given. Increasingly the need for applying an innovation-oriented growth policy which aims at creating new jobs is seen as a promising strategy to tackle the problem of social exclusion. However, traditional innovation policy, aiming at encouraging major technological breakthrough, seems to be less effec- tive in creating new jobs. Instead, a policy is needed which creates the general conditions for continuous improvement, incremental innovations and continuous learning in as many companies as possible.

\section{* Note}

The present report is based on the following National Reports:

Rik Huys \& Geert Van Hootegem: The Belgian Literature Report for SOWING

Riitta Lavikka \& Katja Uosukainen: The Finnish Literature Report for SOWING

Annaflavia Bianchi: Political programmes and IS strategies in Italy.

Francesco Garibaldo: The Information Society. The Italian Debate.

Maria Luisa Mirabile and Francesca Carrera: Social Exclusion in Production Context. The Italian Case.

António Brandão Moniz and Cláudia Teixeira Gomes: Literature Report - Portuguese Contribution.

Gotthard Bechmann, Günther Frederichs: The German Literature Report for SOWING.

Huws, U., Dench S., Jagger N., O'Regan, S.: SOWING Social Exclusion, Work and Information Society: Literature Review UK.

Jörg Flecker, Thomas Riesenecker-Caba, Christian Stary: Information Society, Work and the Generation of New Forms of Social Exclusion.

Sean O Siochru, Bob Jordan, Ruth Taillon: Literature Report Ireland.

Gerd Schienstock: Information Society, Work and the Generation of New Forms of Social Exclusion. A Conceptual Framework.

\section{Footnotes}

1 This section is based on the British and the German reports.

2 This chapter draws extensively on the German report.

3 This section draws extensively on the German report.

4 This section is based on the British, the Austrian, the Belgian, the Finnish, the Italian and the Irish reports.

5 This section draws extensively on the German report.

6 This chapter draws extensively on the British, the German and the Italian reports. 


\section{References}

Aglietta, M. (1976): Régulation et crise du capitalisme: l'expérience des Etats-Unis. Paris, CalmannLevy.

Alasoini, T. (1998) Organizational Innovations as a Source of Competitive Advantage - New Challenges for Finnish Companies and the National Workplace Development Infrastructure. An unpublished paper.

Altmann, N., Deiss, M., Doehl, V. \& Sauer, D. (1986): Ein "Neuer Rationalisierungstyp" - neue Anforderungen an die Industriesoziologie. Soziale Welt; H. 2/3; Jg 37.

Amin, A. (1993): The Globalization of Economy: An Erosion of Regional Networks? In: Grabher, G. (Ed.) The Embedded Firm: On the Socioeconomics of Industrial Networks, London.

Amin, A. (Ed.) (1994): Post-Fordism: A Reader (Studies in Urban and Social Change). Blackwell, Oxford.

Anderson, A. \& Marshall, V. (1996): Core Versus Occupation-specific Skills, DfEE Research Series RS12, London.

Aoki, A. (1989): 'Global Competition, from Organisation and TFP. A Comparative Micro-Perspective'. Paper presented at the International Seminar of Science, Technology and Economic Growth, Paris.

Archibugi, D., Howells, J. \& Michie, J. (1998): Innovation Systems in a Global Economy. CRIC Discussion paper No 18, August 1998, CRIC, The University of Manchester.

Atkinson, J. (1995): New Forms of Work, IES, Report Number 264.

Baethge, M. \& Oberbeck, H. (1986): Zukunft der Angestellten. Neue Technologien und berufliche Perspektiven in Büro und Verwaltung. Frankfurt/M.

Bangemann, Martin: Europe and the global information society. Recommendations to the European Council. CEC: Brüssel 1994.

Barley, S.R. (1986): Technology as an Occasion for Structuring: Evidence from Observation of CT Scanners and the Social Order of Radiology Departments, in: Administrative Science Quarterly 31.

Bartram, P. (1992): Business re-engineering: the Use of Process Redesign and IT to Transform Corporate Performance, Business Intelligence.

Baukrowitz (1996): Neue Produktionsmethoden mit alten EDV-Konzepten? In: Schmiede, R. (Hrsg.): Virtuelle Arbeitswelten: Arbeit, Produktion und Subjekt in der Informationsgesellschaft, Berlin: Edition Sigma.

Baukrowitz \& Boes (1996): Arbeit in der "Informationsgesellschaft". In: Schmiede, R. (Hrsg.): Virtuelle Arbeitswelten: Arbeit, Produktion und Subjekt in der Informationsgesellschaft, Berlin: Edition Sigma.

Beatson M. (1995): Labour Market Flexibility, Employment Department, Research Series No 48.

Bell, D. (1989): Die nochindustrielle Gesellschaft. Frankfurt am Main/New York.

Beninger, J.R. (1986): The control revolution. Technological and economic origins of information society. Cambridge.

Berger, U. (1993): Organisationskultur und der Mythos der kulturellen Integration. In: MüllerJentsch, W. (Hrsg.): Profitable Ethik - effiziente Kultur: Neue Sinnstiftungen durch das Management, München und Mering: Rainer Hampp-Verlag.

Bijker, W. \& Law, J. (Eds.) (1992): Shaping Technology/Building Society: studies in socio-technical change, Cambridge/MA, London, MIT Press.

Bijker, W.E. (1993): 'Do Not Despair: There Is Life after Constructivism', Science, Technology and Human Values 18,1, Winter.

Boes, A. (1996): Formierung und Emanzipation. Zur Dialektik der Arbeit in der Informationsgesellschaft. In: Schmiede, R. (Hrsg.): Virtuelle Arbeitswelten: Arbeit, Produktion und Subjekt in der Informationsgesellschaft, Berlin: Ed. Sigma.

Böhme, G. \& Stehr, N. (Eds.) (1986): The Knowledge Society. Dordrecht.

Bohn; R.E. (1994): Measuring and Managing Technological Knowledge, in: Sloan Management Review 1994.

Brandt, G., Kündig, B., Papadimitrou, Z \& Thomae, J. (1978): Computer und Arbeitsprozeß. Eine arbeitssoziologische Untersuchung der Auswirkungen des Computereinsatzes in ausgewählten Betriebsabteilungen der Stahlindustrie und des Bankgewerbes, Frankfurt/New York.

Brown, J.S. and Duguid, P. (1991): Organizational Learning and Communities-Of-Practice: Towards A Unified View Of Working, Learning And Innovation, in: Organization Science 2, 1.

Brown, Phillip (1995): Cultural Capital and Social Exclusion: Some Observations on Recent Trends in Education, Employment and the Labour Market, in: Work, Employment \& Society 1, 9.

Brown, P. and Scase, R. (1994): Higher Education and Corporate Realities: Class, Culture and the Decline of Graduate Careers, London: UCL Press.

Castells, M. (1989): The Informational City. Basil Blackwell.

Castells, M. (1997): The Rise of the Network Society, Maldon Mass./Oxford: Blackwell Publishers. 
Castels, Robert (1992): De l'indigence à l'exclusion: la désaffiliation, in: Donzelot (ed.): Face à l'exclusion : Le modèle francais, Paris: Editions Esprit.

Cohendet, P. \& Llerena, P. (1997): Learning, Technical Change and Public Policy: How to Create and Exploit Diversity, in: Edquist, C. (ed.): Systems of Innovation, Technologies, Institutions and Organizations, London: Pinter.

Cole, $R$. (1981): The Japanese Automobile Industry: Model and Challenge for the Future?, University of Michigan.

Coulson-Thomas, C. (1994): Business Process ReEngineering: Myth and Reality, Kogan Page.

Deutsch, K. (1983): Soziale und politische Aspekte der Informationsgesellschaft. In: Sonntag, P. (ed.): Die Zukunft der Informationsgesellschaft. Frankfurt am Main.

Doleschal, R. (1991): 'Neue Logistikkonzepte der bundesdeutschen Automobilindustrie als Antwort auf den internationalen Strukturwandel und die Folgen für die Beschäftigten', in: Flecker, J. and Schienstock, G. (Eds.), Flexibilisierung, Deregulierung und Globalisierung. Mering: Hampp-Verlag.

Earl, M. (1996): Knowledge Strategies: Propositions From Two Contrasting Industries. In: Earl, M. (Ed): Information Management. The Organizational Dimension, Oxford: Oxford University Press.

Eason, K. (1988): Information Technology and Organisational Change, London/New York/Philadelphia: Taylor \& Francis.

Enquete Kommission (1998): Deutschlands Weg in die Informationsgesellschaft. Zukunft der Medien in Wirtschaft und Gesellschaft. Deutscher Bundestag (Ed.) Bonn: ZV Zeitungs-Verlag Service.

Ernst, D. \& Lundvall, B.-A. (1997): Information Technology in the Learning Economy - Challenges for Developing Countries, DRUID Working Paper No. 97-12 of the Danish Research Unit for Industrial Dynamics, Aalborg.

European Commission (1993): White Paper: Growth, competitiveness, employment, Luxembourg.

Evans, M., Paugam, S. \& Prelis, J.A. (1995): Chunnel Vision: Poverty, social exclusion and the debate on social welfare in France and England, Discussion Paper 115, Welfare State Programme, London School of Economics.

Fernie, S. \& Metcalfe, D. (1987): (Not) Hanging on the Telephone: Payment Systems in the New Sweatshops; Centre for Economic Performance Discussion Paper 390.

Fleck, J. (1993): Configurations; Cristallyzing Contingency, in: The International Journal of Human Factors in Manufacturing, Vol. 13 (1).
Forester, T. (1980): The microelectronic revolution: the complete guide to the new technology and its impact on society. Blackwell, Oxford.

Foucauld, Jean-Baptiste de (1992): Exclusion, inegalités et justice sociale, in: Esprit (Paris) 182 (juin).

Fourastie, J. (1954): Die große Hoffnung des 20. Jahrhunderts. Köln.

Freeman Ch. (1987): The case for technological determinism. In: Finnigan, R., Salomon, G. \& Thompson, K. (Eds.). Information Technology: Social issues. Kent.

Fulk, J. \& deSantis, G. (1995): Electronic Communication and Changing Organizational Forms, in: Organization Science, Vol. 6, No 4.

Gershuny, J. (1983): Social Innovation and the Division of Labour. Oxford University Press.

Gershuny, J. \& Miles, I. (1983): The new service economy: The transformation of employment in industrial societies, London: Frances Pinter.

Giddens, A. (1979): Central Problems in Social Theory: Action, Structure and Contradiction in Social Analysis, London.

Giddens, A. (1993): New Rules of Sociological Method, Second Edition. Cambridge, England: Polity. (First edition published by Hutchinson in 1976).

Glazer, R. (1991): Marketing in an InformationIntensive Environment: Strategic Implications of Knowledge as an Asset, in: Journal of Marketing, 55.

Gould St.J. (1980): The Panda's Thumb: More Reflections on Natural History, New York: W.W. Norton.

Harris, C.C. (1980): Fundamental Concepts and the Sociological Enterprise, London.

Hart, R. (1987): Working Time and Employment, Allen and Unwin.

Hay, E.J. (1988): Just-In-Time Breakthrough: Implementing the New Manufacturing Basics, Wiley.

Hedlund, G. \& Rolander, D. (1990): Action in Heterarchies - New Approaches to Managing the MNC, in: Bartlett, C.A., Doz., \& Hedlund, G. (eds.): Managing the Global Firm, London/New York: Routledge.

Hendricks, C.F. (1992): The rightsizing remedy. Business One Irwin, Illinois.

Hensel, Matthias: Die Informationsgesellschaft. Neuere Ansätze zur Analyse eines Schlagwortes: München: R. Fischer 1990.

High Level Group on the Information Society (1994): Europe and the global information society: Recommendations to the European Council, Brussels. 
Huws, U. (1990): 'Pinning down the mobile worker' in Practical Computing, March.

Huws, U. (1994): Home Truths: Results from the NGH National Homeworking Survey, National Group on Homeworking, Leeds.

Huws, U. (1998): Flexibility and Security: Towards a New European Balance, Citizens Income Trust, London.

Huws, U., Hurstfield, J. \& Holtmaat, R. (1989): What Price Flexibility?: the Casualisation of Women's Employment, Low Pay Unit, London.

Huws, U., Podro, S., Gunnarsson E., Weijers, T., Arvanaki, K. \& Trova, V. (1996): Teleworking and Gender, IES Report No. 317, Brighton.

Huys, R. et al (1995): De uitgestelde transformatie: sociaal-organisatorische herstructureringen in de chemische, automobiel- en machine-bouwsector, Brussel.

Incomes Data Services (1997): Pay and Conditions in Call Centre, IDS Report 739, London.

Ito, $Y$. (1989): Information Studies Today. In: Schenk, M.; Donnerstag, J. (Eds.), Medienökonomie, München.

Jessop, B. (1991): Fordism and Post-Fordism. A Critical Reformulation, Lancaster Regionalism Group, Working Paper 41/1991.

Kavangh, D. \& Arujo, L. (1997): Folding and unfolding time. Accounting Management and Information Technology 5/2.

Keen, P.G.V. and Scott Morton, M.S. (1978): Decision Support Systems: An Organisational Perspective. Addison-Wesley.

Kern, H. \& Schumann, M. (1984): Ende der Arbeitsteilung? Rationalisierung in der industriellen Produktion: Bestandaufnahmen Trendbestimmung, München.

Kling, R. (1987): 'Defining the boundaries of computing across complex organisations', in Critical Issues in Information Systems Research (Eds. R. Boland and R. Hirschheim), Wiley, New York.

Krämer, S. (1989): Geistes-Technologie. Über syntaktische Maschinen und typographische Schriften. In: Rammert, W. \& Bechmann, G (Hrsg.): Technik und Gesellschaft. Jahrbuch 5: Computer, Medien, Gesellschaft, Frankfurt/New York.

Kubicek, H. (1995): "The Organisation Gap in Large-Scale EDI Systems". In: Williams, R. (Ed.): The social shaping of interorganisational IT systems and electronic data interchange. Proceedings of the PICT/COST A4 International Workshop, Edinburgh University, Edinburgh, European Commission, Directorate General, Science, Research and Development.
Kubicek, H. \& Berger, P. (1990): Was bringt uns die Telekommunikation? ISDN - 66 kritische Antworten. Frankfurt am Main/New York.

Lamming, (1993): Beyond Partnership: Strategies for Innovation and Lean Supply, Prentice-Hall.

Lash, S. (1994): Reflexivity and its Doubles: Structure Aesthetics, Community, in: Beck, U., Giddens, A. \& Lash, S. (eds.): Reflexive Modernisation. Politics, Tradition and Aesthetics in the Modern Social Order, Cambridge: Polity Press.

Leavitt, M.J. \& Whisler, T.L. (1958): 'Management in the 1980s', Harvard Business Review, vol. 36, no.1.

Lillrank, P. with Holopainen, S., Lehtovaara, M. \& Sippa, S. (1996): The Impact of Information and Communication Technologies (ICT) on Business Performance. A Constructive Empirical Study and Philosophical Enquiry, Otaniemi.

Ling, R.C. \& Goddard, W.E. (1988): Orchestrating Success: Improve Control of the Business with Sales and Operations Planning, Oliver Wight.

Löffelholz, M. (1993): Auf dem Weg in die Informationsgesellschaft. Konzepte - Tendenzen - Risiken. In: Hessisches Kultusministerium (Eds.). Zukunftsdialog zu Lehren und Lernen: Angebote. Wiesbaden. Lucas, H.C. Jr. \& Barondi, J. (1994): The Role of Information Technology in Organisation Design. In: Journal of Management Information Systems 10, 4.

Luhmann, N. (1990): Die Wissenschaft der Gesellschaft, Frankfurt/M.

Luhmann, N. (1994): Inklusion und Exklusion: Nationales Bewußtsein und kollektive Identität: Studien zur Entwicklung des kollektiven Bewußtseins in der Neuzeit 2; hrsg. v. Helmut Berding; Frankfurt am Main: Suhrkamp.

Lundvall, B-A \& Johnson, B. (1993): The learning economy, in: Journal of Industry Studies, 1, 2.

Lyon, D. (1988): The Information Society. Issues and Illusions, Cambridge, Mass.: Polity Press.

Machlup, F. (1962): The production and distribution of knowledge in the United States. Princeton University Press, Princeton.

Malsch,T \& Seltz, R. (1987): Die aktuelle Diskussion ueber die Entwicklung neuer Produktions- und Rationalisierungsmodelle zue Einführung. Die neuen Produktionskonzepte auf dem Prüfstand: Beiträge zur Entwicklung der Industriearbeit; Thomas Malsch; Rüdiger Seltz (Ed.); Berlin; Ed. Sigma. REIHE: Wissenschaftszentrum Berlin für Sozialforschung, Forschungsschwerpunkt Arbeitspolitik.

Mathews, J. (1996): Organisational foundations of the knowledge-based economy, in: Employment and Growth in the Knowledge-based Economy, Paris, OECD. 
Miles, I. (1988): Information technology and information society: options for the future; London ESRC.

Miles, I. \& Robins, K. (1994): Making sense of information, in: Robbins, K. (ed.), Understanding Information Business, Technology and Geography, London/New York: Belhaven Press.

Miles, I. \& Kastrinos, N, with Flanagan, K., Bilderbeek \& den Hertog, P. with Huntink, W. \& Bouman, $M$. (1995): Knowledge-Intensive Business Services: Users, Carriers and Sources of Innovation. In: European Innovation Monitoring System (EIMS), EIMS Publication $\mathrm{N}^{\circ} 15$.

Murray, F. (1987): 'Flexible Specialisation in the Third Italy' in Capital and Class, No. 33, Winter.

Murray, F. (1988): 'Life after Henry (Ford)', Marxism Today, Vol. 33.

Nasse, Phillipe (1992): Exclus et exclusions. Connaitre les populations, comprendre les processus, Paris, Commissariat Général du Plan, Jan.

Naschold, F. (1986): Politik und Produktion. Thesen zur Politik und Technologieentwicklung. In: Hartwich, H.H. (ed.): Politik und die Macht der Technik, Opladen.

Nora and Minc (1979): Die Informatisierung der Gesellschaft, Frankfurt am Main.

OECD (1981): Information activities, Electronics and Telecommunications technologies. vol 1, OECD (ICCP series), Paris

OECD (1995): Rapport interimáire sur la technologie, la productivité et la création d'emplois, OECD, Paris.

Pacey, A. (1983): The Culture of Technology, Oxford/New York.

Parker, H. (1995): Taxes, Benefits and Family Life. The Seven Deadly Traps, Institute of Economic Affairs, London.

Parmentier, K. et al (1993): Berufs- und Erwerbsstrukturen West- und Ostdeutschlands in Vergleich. Ergebnisse aus der BiBB/IAB-Erhebung 1991/92. BeitrAB 176, Nürnberg 1993.

Paugam, Serge (1993): La société fraincaiseet ses pauvres, Paris: Presses Universitaires de France.

Perez , C. (1983): Structural Change and the assimilation of new technologies in the economic and social system, in: Futures, 15.

Peters, H.-P. (1994): Risikokommunikation in den Medien, in: Merten, K/Schmidt, S.J./Weischenberg, S. (Eds.): Die Wirklichkeit der Medien Opladen, 1994.

Phizacklea, A. \& Wolkowitz, C. (1995): Homeworking Women: Gender, Racism and Class at Work, Sage, London.
Piore, M.J. \& Sabel, Ch. (1984): The Second Industrial Divide - Possibilities for Prosperity, New York: Basic Books.

Porat, M.U. (1976): The Information Economy. Standford University.

Quaestor Research and Marketing Strategists Ltd (1996): Employment Skills Development Project: A Report on Findings, prepared on behalf of Leeds TEC.

Quinn, J.B. (1986): Technology adoption: the service industries, in: Landau, R. \& Rosenberg, N. (Eds.): The Positive Sum Strategy, Washington DC: National Academy Press.

Reardon, G. (1996): 'Externalising Information Processing Work: Breaking the Logic of Spatial and Work Organisation', United Nations University Institute for New Technologies Conference on Globalised Information Society: Employment Implications, Maastricht.

Reich, Robert, B. (1992): The Work of Nations: Preparing ourselves for $21^{\text {st }}$ Century Capitalism, New York: Vintage.

Riegler, C.H. (1998): Learning from experiences of the Swedish Working Life Fund: new public policy initiatives. In Alasoini, T. and Kyllönen, M. (Eds.) The Crest of the Wave, Reports of the Finnish National Workplace Development Programme 5, Helsinki, Finnish Ministry of Labour.

Robins, K. \& Webster, F. (1997): From ICTs to Information: Changing Conceptions of the Information Age, to be published in: Information, Communication and Society.

Roobeek, A. (1987): 'The crisis in Fordism and the rise of the a new technological paradigm', Futures, 19 (2).

Room, G. et al. (1992): Observatory on national policies to combat social exclusion. Second Annual Report. Report to the Commission of the European Communitties. Lille, European Economic Interest Group: Animation and Research.

Rostow, W.W. (1960): Stadien wirtschaftlichen Wachstums. Göttingen.

Rustin, M. (1989): The politics of post-Fordism: or, the trouble with "new times", New Left Review, (175).

Sahay, S. (1997): Implementation of Information Technology: A Time-Space Perspective. In: Organization Studies 18, 2.

Salais, $R$. (1980): Le chomage: un phénomène de file d'attente. In: Economie et statistique (Paris), No 123 , July.

Sampler, J. (1996): Exploring the Relationship Between Information Technology and Organizational Structure. In: Earl, M. (Ed): Information Manage- 
ment. The Organizational Dimension. Oxford: Oxford University Press.

Schienstock, Gerd. (1993): Management als sozialer Prozeß. Theoretische Ansätze zur Institutionalisierung. In: Ganter, H.-D. \& Schienstock, G (Hrsg.): Management aus soziologischer Sicht. Unternehmungsführung, Industrie- und Organisationssoziologie. Wiesbaden: Gabler Verlag.

Schienstock, Gerd (1997b): Probleme der Koordinierung, Steuerung und Kontrolle einer globalen Ökonomie. In: Blättel-Mink, Birgit und Renn, Ortwin (Hrsg.): Zwischen Akteur und System. Die Organisation von Innovation. Opladen: Westdeutscher Verlag.

Schimank, U. (1986): Technik, Subjektivität und Kontrolle in formalen Organisationen eine Theorieperspektive Organisation als soziales System: Kontrolle und kommunikationstechnologie in Arbeitsorganisationen; Rüdiger Seltz; Ulrich Mill; Eckardt Hildebrandt (Eds.); Berlin; Ed. Sigma; pp. 71-91. Reihe: Wissenschaftszentrum Berlin für Sozialforschung, Forschungsschwerpunkt Arbeitspolitik.

Senge, P.M. (1990): The Fifth Discipline. New York: Doubleday.

Sengenberger, Werner and Pyke, Frank (1992): Industrial Districts and Local Economic Regeneration: Research and Policy Issues, in: Pyke, Frank and Sengenberger, Werner (eds.): Industrial Districts and Local Economic Regeneration, ILO Genf.

Silver, Hilary (1994): Social exclusion and social solidarity: Three paradigms. In: International Labour Review, 133, 5-6.

Social Exclusion Unit (Ed.) (1998): Bringing Britain together: a national strategy for neighbourhood renewal. Report presented to Parliament by the Prime Minister by Command of Her Majesty, September.

Soete, L. (1996): Social impacts of the information society - National and community level, in: Finnish Institute of Occupational Health, Work in the Information Society, Helsinki.

Somogyi, E.K. and Galliers, R.D. (1997): Information technology in business: from data processing to strategic information systems. In: Galliers, R.D. and Baker, B.S.H: Strategic Information Management: Challenges and Strategies in Managing Information Systems.

Steinmüller, W. (1981): Die zweite industrielle Revolution hat eben begonnen, in: Kursbuch 66.

Stichweh, Rudolf (1997): Inklusion/Exklusion, funktionale Differenzierung und die Theorie der Weltgesellschaft. Soziale Systeme; 1, 3.

Strassman, P.A. (1990): The Business Value of Computers, USA: The Information Economic Press.
Streeck, W. (1989): Interest Heterogeneity and Organizing Capacity: Two Class Logics of Collective Action?, Discussion Paper FS I 1989/4, Wissenschaftszentrum Berlin.

Toffler, A. (1980): The Third Wave. Bantam Books. Tomasko, R.M. (1990): Downsizing: reshaping the corporation for the future, Amacom, New York.

Touraine, A. (1969): La Société post-industrielle, Paris: Denoel.

Touraine, A. (1991): Face à l'exclusion, in: Esprit (Paris) 169 (February).

Tulder, R. van \& Junne, G. (1988): European Multinationals in Core Technologies, New York: John Willy.

Valenduc, G \& Vendramin, P. (1998): Le travail á distance dans la société de l'information, Bruxelles.

Wagner, I. (1994): Hard times, the politics of women's work in computerised environments. Women, work and computerisation: breaking old boundaries - building new forms; ed. by Alison Adam, Judy Emms, Eileen Green, Jenny Owen; Amsterdam; Elsevier Scientific Publ. Co.; pp. 23-24. REIHE: IFIP Transactions A: Computer Science and Technology; A-57. KONFERENZ: International Conference "Women, Work and Computerization: Breaking Old Boundaries - Building new Forms" 5, Manchester.

Walsh, J. \& Ungson, G. (1991): Organizational Memory. Academy of Management Review, 16.

Walsham, G. (1993): Interpreting Information Systems in Organisations, Chichester, John Wiley \& Sons.

Werle, R. (1990): Telekommunikaiton in der Bundesrepublik, New York/Frankfurt/M.

Wehrsig, Ch. \& Tacke, V. (1992): Funktionen und Folgen informatisierter Organisationen. ArBYTE: Modernisierung der Industriesoziologie?; Thomas Malsch; Ulrich Mill (Eds.); Berlin; Ed. Sigma.

Wittke, V. (1990): 'Systemische Rationalisierung zur Analyse aktueller Umbruchprozesse in der industriellen Produktion'. In Bergstermann, J. and Brandherm-Bhmker, R. (Eds.), Systemische Rationalisierung als sozialer Prozess. Bonn: Dietz.

Womack, J., Jones, D. \& Roos, D. (1990): The Machine that Changed the World. London, Macmillan.

Wyatt, S. (1998): Technology's Arrow. Developing Information Networks for Public Administration in Britain and the United States, Proefschrift, Universitaire pres Maastricht.

Xiberras, Martine (1993): Les théories de l'exclusion. Paris: Meridiens Klincksieck.

Yépez del Castillo, Isabel (1994): A comparative approach to social exclusion: Lessons from France 
and Belgium, in: International Labour Review, 133, 5-6.

Zeitlin, J. (1991): 'Reconfiguration of the Market and the Use of Computerised Technology' in Mitter, S. (Ed.), (1991) Computer-aided Manufacturing and Women's Employment, Springer-Verlag, London.

》

\section{"Standortdebatte" und "Neue Armut": Bundesdeutsche Illu- strationen zum EU-Projekt SOWING}

\author{
von Günther Frederichs, ITAS
}

\section{Gibt es nationale Sonderwege in die "Informationsgesellschaft"?}

Das EU-Projekt SOWING spannt den Bogen seiner Themen von den Kommunikations- und Informationstechnologien über die technologische Praxis von Wirtschaftsunternehmen bis hin zu neuen Formen sozialer Ausgrenzung. Damit wird von vornherein eine auf die technologische Entwicklung verengte Perspektive vermieden und es werden die Wechselwirkungen mit anderen gesellschaftlichen Vorgängen in die Beobachtung mit einbezogen. Überraschenderweise kann die "Informationsgesellschaft" auch bei dieser komplexeren Betrachtungsweise immer noch unabhängig von den nationalen Besonderheiten eines Landes beschrieben werden, zumindest in erster Annäherung. Die Ausgangsbedingungen sind diejenigen, die generell in den Industrienationen am Ende des 20. Jahrhunderts vorzufinden sind - ein bemerkenswerter Aspekt der These vom Entstehen einer globalen Gesellschaft, wie es die Theoretiker der Moderne sehen!

Wenn es jedoch darum geht, die Hypothesen und Prognosen empirisch zu verifizieren, und wenn ein Vergleich der technologischen Praxis in verschiedenen europäischen Regionen vorgenommen werden soll, dann rücken die jeweiligen Kontexte als "intervenierende Variable" ins Bild. $\mathrm{Zu}$ fragen ist dann, aus welchen nationalen Erfahrungen sich die Diskussion speist und welches die Entwicklungen eines
Landes sind, deren Extrapolationen und Verallgemeinerungen in die Prognose der Informationsgesellschaft einmünden. Wenn es nationale Sonderwege in die Informationsgesellschaft gibt, dann sind es spezifische Konstellationen der jeweiligen Länder, die der Entwicklung eine spezielle Ausprägung geben. Angesichts der vielbeschworenen Vielfalt der Länder und Kulturen Europas sollte man unterschiedliche $\mathrm{Mu}$ ster der Entwicklung erwarten.

Welche Kontexte in die Beobachtung einbezogen werden, ergibt sich aus den zentralen Themen von SOWING: die technologische Praxis von Wirtschaftsunternehmen und die Entstehung neuer Formen sozialer Ausgrenzung am Arbeitsmarkt. Sie lenken den Blick auf das unternehmerische Handeln im Rahmen des jeweils geltenden Produktions- und Regelungsmodells (Czada 1998). Durch die Verwendung des lebensweltlichen Begriffs der "Praxis" öffnet sich der Blick den vielfältigen demographischen, infrastrukturellen und kulturellen Einflüssen. Es ist nicht zuletzt das System der industriellen Beziehungen, in dem die Konfliktkultur eines Landes zum Ausdruck kommt und so der technologischen Praxis einer Firma eine nationale Färbung gibt.

\section{Das "Modell Deutschland" und die Standortdebatte}

Die wohlfahrtsstaatliche Einbettung der westdeutschen Marktwirtschaft besteht traditionell in "verbandlicher Selbststeuerung": Gewerkschaften, Arbeitgeberverbände und Industrievereinigungen regulieren wichtige Bereiche autonom oder im Austausch mit staatlichen Instanzen. Diese nach dem Konsensprinzip funktionierende Konfiguration konnte bis zur Wiedervereinigung die wichtigsten Voraussetzungen des einst international gepriesenen "Modells Deutschland" erfolgreich realisieren: die Wettbewerbswirtschaft, die sektorale Selbstorganisation, die Strukturpolitik auf Länderebene, die Tarifautonomie und last not least das Wirtschaftswachstum (Czada 1998). Die wesentlichen Merkmale sind

- die Einbindung von Gewerkschaften und Wirtschaftverbänden in die allgemeine Wirtschaftspolitik ("Konzertierte Aktionen", "Bündnis für Arbeit") 